\title{
Managerial Overconfidence and Corporate Risk Management-
}

\author{
Tim R. Adam \\ School of Business and Economics, Humboldt University of Berlin \\ Dorotheenstr. 1, 10099 Berlin, Germany \\ Tel.: +49 302093 5641; Fax: +49 3020935643 \\ E-mail:tim.adam@hu-berlin.de \\ Chitru S. Fernando \\ Price College of Business, University of Oklahoma \\ 307 West Brooks, Norman, OK 73019, USA \\ Tel.: (405) 325-2906; Fax: (405) 325-7688 \\ E-mail: cfernando@,ou.edu \\ Evgenia Golubeva \\ Price College of Business, University of Oklahoma \\ 307 West Brooks, Norman, OK 73019, USA \\ Tel: (405) 325-7727; Fax: (405) 325-7688 \\ E-mail:janya@,ou.edu
}

July 2015

\begin{abstract}
We examine whether managerial overconfidence can help explain the observed discrepancies between the theory and practice of corporate risk management. We use a unique dataset of corporate derivatives positions that enables us to directly observe managerial reactions to their (speculative) gains and losses from market timing when they use derivatives. We find that managers increase their speculative activities using derivatives following speculative cash flow gains, while they do not reduce their speculative activities following speculative losses. This asymmetric response is consistent with the selective selfattribution associated with overconfidence. Our time series approach to measuring overconfidence complements cross-sectional approaches currently used in the literature. Our results show that managerial overconfidence, which has been found to influence a number of corporate decisions, also affects corporate risk management decisions.
\end{abstract}

JEL Classification: G11; G14; G32; G39

Keywords: corporate risk management; selective hedging; speculation; managerial overconfidence

"We thank an anonymous referee for helpful suggestions. We thank Gregory Brown, Alex Butler, Sudheer Chava, Louis Ederington, Gary Emery, Dirk Jenter, Swami Kalpathy, Leonid Kogan, Shimon Kogan, Nan Li, Gustavo Manso, Bill Megginson, Darius Miller, Jun Pan, Roberto Rigobon, Martin Ruckes, Antoinette Schoar, Oliver Spalt, Per Stromberg, Rex Thomson, Pradeep Yadav, and seminar participants at MIT, University of Oklahoma, Humboldt University, University of Texas at Dallas, Southern Methodist University, Texas Christian University, Tulane University, ESMT Berlin, American Finance Association annual meetings, European Finance Association annual meetings, Financial Management Association (FMA) annual meetings, and FMA Europe annual meetings for valuable discussions and comments. We are grateful to Ted Reeve for providing us with his derivatives surveys of gold mining firms and Leung Kam Ming for excellent research assistance. We also thank Anthony May and Jesus Salas for valuable assistance. This research has been partially supported by the Research Grants Council of Hong Kong (Grant No. HKUST6138/02H). Chitru Fernando thanks the National Science Foundation (Grant No. ECS0323620) for financial support. We are responsible for any remaining errors. 


\section{Introduction}

The traditional theories of corporate risk management show that reducing risk can increase shareholder value by reducing expected taxes, bankruptcy costs, agency costs, information asymmetries, and payments to undiversified stakeholders of the firm. ${ }^{1}$ However, empirical tests of the predictions of these theories have met with only limited success. ${ }^{2}$ While each empirical study uncovers evidence that can be interpreted as being consistent with one or more of the theories of hedging, there is little consistency across studies. In addition, much of the variation in firms' derivatives strategies, both cross-sectionally and over time, remains unexplained. This disparity between theory and practice is remarkably consistent with an argument advanced 50 years ago by Working (1962), that the "traditional" risk avoidance notion of hedging - matching one risk with an opposing risk - is deficient when it comes to explaining hedging behavior in practice. Indeed, there is growing evidence that many managers systematically incorporate their market views into corporate risk management programs. ${ }^{3}$ Stulz (1996) argues that this practice of selective hedging may be economically justified if the firm has private market information. But he also highlights the danger that some firms may engage in selective hedging by overestimating the superiority of their information relative to the market. Indeed, recent empirical evidence that firms fail to generate positive cash flows, on average, from selective hedging is consistent with the possibility that managerial overconfidence may sub-optimally bias corporate decisions pertaining to risk management. ${ }^{4}$ In this paper, we provide direct new evidence of how managerial

\footnotetext{
${ }^{1}$ See, for example, Stultz (1984), Smith and Stultz (1985), Froot, Scharfstein and Stein (1993), DeMarzo and Duffie (1995), Leland (1998), Breeden and Viswanathan (1998) and Mello and Parsons (2000).

${ }^{2}$ See, for example, Tufano (1996), Mian (1996), Graham and Smith (1999), Haushalter (2000) and Graham and Rogers (2002).

${ }^{3}$ See, for example, Dolde (1993), Stultz (1996), Bodnar, Hayt and Marston (1998), and Glaum (2002).

${ }^{4}$ See Adam and Fernando (2006) and Brown, Crabb and Haushalter (2006).
} 
overconfidence influences corporate risk management decisions by studying the risk management activities of a sample of North American gold mining firms. Our findings add to a growing literature, both theoretical and empirical, that studies the impact of overconfidence and other managerial biases on corporate investment policies, capital structure decisions, innovation, mergers and acquisitions, security offerings, and investment bank relationships. ${ }^{5}$

In the context of corporate hedging, the managerial overconfidence hypothesis (e.g., Heaton (2002); Malmendier and Tate (2005, 2008)), implies that managers may be overconfident in their ability to predict future market movements, causing them to engage in excessive shifting of derivatives positions under the mistaken belief that they have a relative information advantage. In particular, overconfidence is expected to increase following successes, but decrease less (if at all) following failures. This asymmetric response follows from selective selfattribution: successes tend to be attributed to one's own skill, while failures tend to be attributed to bad luck.

We provide strong evidence that is consistent with this behavioral pattern in our study of corporate hedging. Our unique data set contains quarterly observations of all outstanding gold derivatives positions of a sample of 92 North American gold mining firms from 1989-1999. The key advantage of this data set is that we are able to infer actual derivatives transactions and the corresponding derivatives cash flows. We measure selective hedging by the time-series volatility in a firm's hedge ratio (fraction of production hedged). We measure the performance of firms' derivatives activities by first computing the quarterly total cash flows generated from derivatives positions per ounce of gold hedged and then recalculating the quarterly cash flows assuming a

\footnotetext{
${ }^{5}$ Studies include Roll (1986), Loughran and Ritter (2002), Heaton (2002), Jaggia and Thosar (2004), Ljungqvist and Wilhelm (2005), Malmendier and Tate $(2005,2008)$, Billett and Qian (2008), Goel and Thakor (2008), Sautner and Weber (2009), Gervais, Heaton and Odean (2009), Grundy and Li (2010), Ang and Mauck (2011), Malmendier, Tate and Yan (2011), Neupane and Poshakwale (2012), and Ben-David, Graham and Harvey (2013). Baker, Ruback, and Wurgler (2007) provide a comprehensive review of the literature on behavioral corporate finance.
} 
firm had maintained a constant hedge ratio. We attribute the difference between the total derivatives cash flow and the fixed hedge benchmark cash flow to selective hedging. ${ }^{6}$ Positive selective hedging cash flows constitute "speculative gains" and negative selective hedging cash flows constitute "speculative losses." Therefore, selective hedging cash flows provide a direct measure of the cash flow consequences of managerial market timing.

We find that managers increase the level of their speculative activities using derivatives following speculative gains, but do not commensurately reduce their speculative activities following speculative losses. This asymmetric response, which persists after controlling for firm fixed-effects and several other time-varying firm characteristics, is difficult to reconcile with rational theories of risk management, but is consistent with the presence of managerial overconfidence. Explicitly recognizing the tendency for some managers to engage in hedging practices based on a systematic overestimation of their ability to predict future market movements improves our understanding of corporate risk management decisions and helps close the gap between the observed practice of risk management and the extant theories that seek to explain it.

We also contribute to the literature by directly measure managerial overconfidence using a time series approach that is distinct from and complements approaches employed in recent empirical studies. Malmendier and Tate (2005) develop a cross-sectional measure of managerial overconfidence based on the deliberate overexposure of CEOs to the idiosyncratic risk of their firms as measured by their unwillingness to exercise vested options and propensity to habitually increase their holdings of their firm's stock. They show that these overconfidence measures are systematically related to the tendency for such managers to overinvest internal funds based on

\footnotetext{
${ }^{6}$ Adam and Fernando (2006) provide details on the computation of these cash flows.
} 
their tendency to overestimate the return to their investment projects, while Malmendier, Tate and Yan (2011) show that overconfident managers use less external finance and issue less equity when they do. Using the same late option exercise measure of overconfidence, Malmendier and Tate (2008) find a systematic relation between CEO overconfidence and their tendency to undertake value-destroying mergers, showing that the odds of making an acquisition is $65 \%$ higher if a CEO is overconfident. Billett and Qian (2008) measure overconfidence by studying serial acquirers and show that more frequent acquirers display more overconfidence as evidenced by the negative wealth effects associated with subsequent acquisitions and the tendency for such CEOs to make net purchases of the firm's stock that are higher for subsequent deals than for the initial acquisition despite the negative wealth effects of subsequent deals. The focus in these studies is on whether cross-sectional differences across managers explain actions that are attributable to overconfidence. Our work complements the prior studies by focusing on timeseries patterns that allows us to directly measure how managers as a group respond to their own past performance. As noted before, this complementary perspective is made possible by our unique data set, which allows us to directly measure the cash flows derived from derivatives positions and how the propensity of managers to engage in selective hedging is related to these cash flow observations.

The remainder of the paper is organized as follows. Section 2 discusses the relevant literature and derives testable hypotheses. Section 3 describes our sample, the construction of our variables and the empirical methodology. Section 4 presents the empirical evidence on how speculation responds to speculative gains and losses. Section 5 summarizes the results and presents our conclusions. 


\section{Empirical Hypotheses}

As documented by Baker, Ruback, and Wurgler (2007) in their excellent review of the growing literature on behavioral corporate finance, several managerial behavioral biases have been shown to affect corporate decisions. Managerial overconfidence has been widely documented in the literature (see, for example, Russo and Schoemaker (1992), Griffin and Tversky (1992) and Heaton (2002)). Overconfident managers systematically overestimate the probability of good outcomes (and correspondingly, underestimate the probability of bad outcomes) resulting from their actions (Heaton (2002)). In a dynamic setting, overconfidence coupled with biased selfattribution (Miller and Ross (1975)), where managers credit themselves for successes while blaming outside factors for failures, cause managerial overconfidence to increase following successes but not commensurately decrease following failures (Daniel, Hirshleifer and Subrahmanyam (1998); Gervais and Odean (2001)). The implications for corporate financial decisions are that overconfident managers act more decisively and aggressively, and that this behavior intensifies following successes. Several studies, including Malmendier and Tate (2005, 2008), Billett and Qian (2008), Malmendier, Tate and Yan (2011), and Ben-David, Graham and Harvey (2013) report empirical evidence consistent with overconfident managers, while Barber and Odean (2000) and Neupane and Poshakwale (2012) report similar evidence in the context of overconfident investors.

We test the overconfidence hypothesis in the context of corporate risk management. There is ample evidence that managers incorporate their market views into their hedging decisions, and thus hedge "selectively."7 Adam and Fernando (2006) and Brown, Crabb and Haushalter (2006) document significant time-series variation in the size of the hedge positions of

\footnotetext{
${ }^{7}$ See Dolde (1993), Stultz (1996), Bodnar, Hayt and Marston (1998), and Glaum (2002).
} 
gold mining firms, which may reflect managers' changing market views about future gold prices. In the absence of an information advantage with respect to gold prices, however, incorporating a manager's private market view into a hedging program is inconsistent with extant theories of risk management. Indeed, Adam and Fernando (2006) and Brown, Crabb and Haushalter (2006) do not find systematic gains from selective hedging, which implies that managers of gold mining firms do not possess an information advantage on average. ${ }^{8}$ Thus, the significant time-series variation in firms' hedge positions is unlikely to be consistent with rational explanations of corporate hedging.

The managerial overconfidence hypothesis applied in the context of corporate speculation implies that managers grow more overconfident following past speculative successes, leading to a more aggressive pursuit of speculative strategies, while past failures would diminish managers' willingness to speculate to a lesser degree, if at all. Hence, we expect an asymmetric relation between speculative activities and the past performance of speculative positions, where managers increase their speculative activities following successes in speculation, while they do not commensurately decrease speculation following failures in speculation.

\section{Data and Methodology}

Our sample consists of 92 gold mining firms in North America, which are included in the Gold and Silver Hedge Outlook, a quarterly survey of derivatives activities conducted by Ted Reeve, an analyst at Scotia McLeod, from 1989 through 1999, when he discontinued the survey. ${ }^{9}$ These

\footnotetext{
${ }^{8}$ In an interesting parallel, Allayannis and Weston (2001) observe that firms that use currency derivatives without having a known foreign currency exposure do not experience a significant increase in Tobin's $Q$.

${ }^{9}$ While some post-2000 hedging data is available from accounting disclosures and other sources, this data lacks the level of detail and consistency across firms that has made the Scotia McLeod survey data invaluable for many empirical studies of corporate hedging, including Tufano (1996, 1998), Fehle and Tsyplakov (2005), Adam and Fernando (2006), and Brown, Crabb and Haushalter (2006).
} 
92 firms represent the majority of firms in the gold mining industry (see Tufano (1996) and Adam and Fernando (2006)). Firms not included in the survey tend to be small or privately held corporations.

The survey contains information on all outstanding gold derivatives positions, their size and direction, maturities, and the respective delivery prices for each instrument (forwards, spotdeferred contracts, gold loans and options). This derivatives data is described in detail in Tufano (1996). We hand-collect operational data: gold production (in ounces), production costs per ounce of gold, and gold reserves, from firms' annual reports. The data on firm characteristics such as size, market-to-book, leverage, liquidity, existence of a credit rating, and payment of quarterly dividends comes from Compustat. Data on managerial compensation is from ExecuComp, supplemented by hand collection from proxy statements where necessary. All variable notations and definitions are provided in Appendix 1.

We measure the extent of derivatives usage at a given point in time $t$ with time to maturity $i$ by a hedge ratio $H R(i)_{t}$, defined as follows:

$$
H R(i)_{t}=\frac{N(i)_{t}}{E_{t}\left[\operatorname{Prod}_{t+i}\right]},
$$

where $N(i)_{t}$ is the sum of the firm's derivatives positions in place at time $t$ (in ounces of gold) that mature in $i$ years, weighted by their respective deltas, as in Tufano (1996). $E_{t}\left[\operatorname{Prod}_{t+i}\right]$ is the firm's expectation of its gold production (in ounces of gold) at time $t+i$ as of time $t$. The maturity $i$ of a derivatives position can be $1,2,3,4$, or 5 years, although most derivatives activity takes place with contracts that mature within three years. To check robustness of our results we aggregate (a) contracts with 1-3 years maturity and (b) contracts with 1-5 years maturity.

The derivatives survey reports the expected production for each hedge horizon $i$ whenever a firm has derivatives positions outstanding that mature in $i$ years. If a firm does not 
hedge a particular maturity, then the expected production figures are missing. In this case we use the actual gold production in year $t+i$. Since most firms do not hedge their gold production beyond three years, the problem of missing expected production figures increases with the hedge horizon. Therefore, we also define an alternate hedge ratio, $H R_{\text {Res }}(i)_{t}$, that does not rely on expected production but scales a firm's total derivatives position by its total gold reserve (see Jin and Jorion (2006)):

$$
H R_{\text {Res }}(i)_{t}=\frac{N(i)_{t}}{\text { Gold Reserve }_{t}}
$$

In addition to helping overcome potential issues associated with missing production data, scaling by reserves is also a useful robustness check of our analysis using production-based hedge ratios, due to the possibility that some time-series variation in the production-based hedge ratio may be due to unplanned variations in expected production rather than a change in the firm's derivatives positions.

We observe the above hedge ratios every quarter from December 1989 to December 1999. This data allows us to measure the extent of speculation (selective hedging) by the timeseries volatility in hedge ratios. To obtain quarterly volatility estimates while also maximizing the number of observations in our relatively small sample, we follow the existing literature on volatility estimation and calculate volatility by the absolute change in a firm's hedge ratio. Alizadeh, Brandt, and Diebold (2002) review the large body of literature that estimates timevarying volatility using two daily observations: either open and close, or high and low. They argue, in particular, that the range, or the difference in log prices between daily high and daily low, is a good proxy for daily volatility. To quote, “...the discretized stochastic volatility model is difficult to estimate because the sample path of the asset price within each interval is not fully observed.... In practice, we are forced to use discretely observed statistics of the sample paths, 
such as the absolute or squared returns over each interval, to draw inferences about the discretized $\log$ volatilities and their dynamics..." The measure advocated by Alizadeh et al. (2002) has been used not only in market microstructure but also, for example, in asset pricing research. Ang, Hodrick, Xing, and Zhang (2006) mention using the range-based volatility measure as a proxy for innovations in aggregate market volatility, in order to estimate whether exposure to these innovations is a priced risk. Thus, we define the extent of speculation in quarter $t, V_{t}$, as the absolute value of the difference in the natural logarithms of the hedge ratios at the beginning and the end of each quarter. ${ }^{10}$

$$
V_{t}=A B S\left[L N\left(H R_{t} / H R_{t-1}\right)\right]
$$

This approach permits us to obtain quarterly volatility estimates, in contrast to (at best) annual volatility estimates that we would obtain using the time-series standard deviation of hedge ratios. $^{11}$

We use several constructs to measure the past performance of firms' derivatives activities. First, we compute the quarterly total cash flows generated from derivatives positions per ounce of gold hedged. Second, we recalculate the quarterly cash flows assuming a firm had maintained a constant hedge ratio ("benchmark cash flows"). The difference between the total derivatives cash flow and the cash flow computed using this fixed hedge ratio benchmark is the cash flow that we attribute to selective hedging. ${ }^{12}$ Positive selective hedging cash flows constitute "speculative gains" and negative selective hedging cash flows constitute "speculative

\footnotetext{
${ }^{10}$ For the purpose of measuring percentage changes, whenever a firm reports a zero hedge (unless it reports a zero value in both the beginning and the end of the quarter), we substitute a very small value. The percentage change is then calculated as the difference of the natural logarithms from quarter ( $t-1)$ to quarter $t$.

${ }^{11}$ An apparent refinement would be to estimate predicted hedge ratios as in Adam and Fernando (2006) and use the hedge ratio residuals to compute speculation. However, as demonstrated by Adam and Fernando (2006) in their robustness checks, speculation computed using hedge ratio residuals does not yield substantively different results to speculation computed using total hedge ratios, which may be due in part to the inability of fundamental variables to explain the variation in hedge ratios.

${ }^{12}$ Adam and Fernando (2006) provide details on the computation of these cash flows.
} 
losses." Selective hedging cash flow is an attractive measure because it reflects the part of the cash flow that results directly from managerial market timing, i.e., speculative, actions. ${ }^{13}$ Finally, in addition to the above cash flow measures, we also calculate the quarterly derivatives book profit (or loss), which is computed as the quarterly change in the value of derivatives positions in dollars per ounce hedged. Please refer to Appendix 2 for the calculation of quarterly changes in the book value of derivatives positions.

Tables 1 and 2 show the descriptive statistics and the correlations for the different hedge ratios and hedge ratio volatility measures.

[Place Tables $1 \& 2$ about here]

Several observations emerge from these tables. Selective hedging cash flows average at around zero, suggesting that consistent with prior studies selective hedging does not significantly increase shareholder cash flows. We notice that the hedge ratios of different maturities are all significantly correlated with one another. However, the correlations are weaker between shortermaturity and longer-maturity hedge ratios. The aggregate hedge ratios are less than perfectly correlated with one another, substantiating the need to check robustness of our results with respect to different hedge ratio definitions. The same general conclusions hold for the hedge ratio volatilities.

\subsection{Basic methodology}

Our basic methodology is to run panel regressions with firm fixed effects in order to focus on the time-series variation in hedge ratios and hedge ratio volatility. Our test of managerial

\footnotetext{
${ }^{13}$ For example, suppose a manager believes that the gold price is going to rise and therefore reduces the hedge ratio relative to the benchmark. If she is correct in her forecast, then the total derivatives cash flow will be negative (since she is short overall) but the selective component will be positive: the firm does not lose as much on the hedge as it could have.
} 
overconfidence, which is based on the relationship between hedge ratio volatility and past speculative gains and losses, needs to be restricted to active hedgers only (i.e., firms that have non-zero hedge ratios and report non-zero cash flows in the previous period). This requirement is due to the fact that the overconfidence hypothesis conditions managerial activity on the results of previous activity. In addition, leaving non-hedging firm-quarters in the sample may lead to a spurious regression result with zero past cash flows from derivatives positions "explaining" zero hedge ratio volatility next period. Hence, we estimate the panel regression with firm fixed effects on a reduced sample of active hedgers.

For robustness we repeat our tests using the two-step Heckman (1979) procedure with selection. In the first stage, we model the existence of hedging activity as a function of variables that are predicted by extant hedging theory to be determinants of hedging -- firm size, market-tobook ratio, liquidity, leverage, dividend payment, credit rating, and the likelihood of financial distress (Tufano (1996), Haushalter (2000)). We say that a firm has hedging activity if two conditions hold: (1) the beginning or the end-of-quarter hedge ratio is non-zero; and (2) cash flows from derivatives positions in the previous quarter are non-zero. In the second stage of the Heckman two-step procedure, we test whether the hedge ratio volatility is driven by past success of the derivatives positions for the firms that exhibit hedging activity as described above. Further methodological details are provided in Section 4.

Our unique data permits us to employ a methodology that is distinct from and complements the techniques employed in recent studies of corporate managerial biases. Malmendier and Tate (2005) develop a cross-sectional measure of managerial overconfidence based on the deliberate overexposure of CEOs to the idiosyncratic risk of their firms as measured by their unwillingness to exercise vested options and propensity to habitually increase their 
holdings of their firm's stock. Malmendier and Tate (2008) find a systematic relation between CEO overconfidence and their tendency to undertake value-destroying mergers, showing that the odds of making an acquisition ("managerial acquisitiveness") is $65 \%$ higher if a CEO is overconfident. Billett and Qian (2008) directly measure overconfidence by acquisitiveness and show that more frequent acquirers display more overconfidence as evidenced by the negative wealth effects associated with subsequent acquisitions and the tendency for such CEOs to make net purchases of the firm's stock that are higher for subsequent deals than for the initial acquisition despite the negative wealth effects of subsequent deals. The focus in these studies is on whether cross-sectional differences across managers explain actions that are attributable to overconfidence. Our work complements the prior studies by focusing on time-series patterns that allows us to directly measure how managers as a group respond to their own past performance.

\subsection{Controlling for alternative explanations}

An alternative explanation for an increase in speculation following high derivatives cash flows derived from speculation is that managers simply have more cash to use at their discretion or that positive cash flows from speculation improve the firm's financial strength. We control for a firm's liquidity and financial strength to account for this possibility by including a dividend dummy, rating dummy, quick ratio, leverage and Altman's (1968) Z-score as control variables. ${ }^{14}$

Another possibility is that although selective hedging does not benefit shareholders, it may benefit managers due to incentive compensation (Stulz (1996)). Adams et al. (2011) point out that managerial incentives in the presence of lax governance monitoring affect the degree to which corporations engage in risk management. While the potential link between selective

\footnotetext{
${ }^{14}$ It is important to note, however, that in contrast to positive speculative cash flows from derivatives, positive total derivatives cash flow need not make the overall financial position of the firm stronger because positive hedge cash flows on derivatives positions would typically offset losses due to gold price declines.
} 
hedging and managerial compensation is explored in recent studies, the results are mixed, with only weak evidence that managerial compensation significantly affects selective hedging and no consensus on the direction of the relationship. ${ }^{15}$ Nevertheless, we control for managerial compensation variables to allow for this possibility in our hedging sample.

Finally, as pointed out by Campbell and Kracaw (1999), financially constrained firms with good projects may speculate more to generate more funds for optimal investment. Investment opportunities may also affect the degree to which firms choose to hedge due to the need to raise external financing (Froot, Scharfstein and Stein (1993)). Campello et al. (2011) show that firms that hedge more have more advantageous financing terms enabling them to increase investment. We account for both financial constraints and growth opportunities by including standard control variables such as debt-to-equity and market-to-book ratios.

\section{Empirical Evidence: Managerial Responses to Speculative Gains and Losses}

In this section, we test the managerial overconfidence hypothesis by examining the relation between speculation (measured by hedge ratio volatility) and past speculative gains and losses. The overconfidence hypothesis maintains that, all else equal, if past speculative activity was successful, resulting in cash flow gains, then the manager will increase his/her speculative activities in the next period. If, however, past speculative activity was unsuccessful, resulting in cash flow losses, then there would be no commensurate reduction in speculative activities. In other words, we expect an asymmetric relation between the degree of speculative activity and past speculative cash flows.

\footnotetext{
${ }^{15}$ Géczy, Minton and Schrand (2007) find that CEO stock price sensitivity is negatively related to speculation while CFO stock price sensitivity is positively related. Brown, Crabb and Haushalter (2006) find no systematic relationship between selective hedging and several ownership and compensation measures.
} 


\subsection{Initial panel regressions without asymmetry effects}

We begin by examining the general relationship between derivatives cash flows and subsequent speculative activity. Tables 3 and 4 show the results of the firm fixed effects panel regressions of the hedge ratio volatility on past cash flows and book profits from derivatives positions per ounce of gold hedged. We present the results for the volatility of the one-year hedge ratio, the three-year aggregate hedge ratio scaled by expected production, the three-year aggregate hedge ratio scaled by reserves, and the five-year hedge ratio scaled by reserves. Table 3 reports the results for a specification that employs total derivatives cash flows along with derivatives book profit as independent variables. Our interest in this specification is to investigate whether speculative activity responds to past derivatives cash flows and/or book profits. Table 4 reports the corresponding results using selective hedging cash flows (i.e., the speculative component of total derivatives cash flows), which is our primary variable of interest.

\section{[Place Tables 3 and 4 about here]}

Since we are interested in testing the hypothesis that successful past speculative derivatives activity will lead to higher speculation in the future, we perform these regressions after eliminating firm quarters where the firm had zero cash flows from derivatives positions, and also eliminating observations where both beginning-of-quarter and end-of-quarter hedge ratios were zero. In all of the models, we include seasonal dummy variables as controls; however, doing so is mostly due to a concern with the one-year hedge ratio, which exhibits some seasonal variation, whereas the aggregate hedge ratios exhibit virtually no seasonal variation. As discussed in Section 3.2, we also control for firm characteristics that may affect a firm's level of speculative activity, such as liquidity, financial strength, and growth opportunities. 
As evident from Table 3, we observe a positive relationship between hedge ratio volatility and previous quarter total derivatives cash flows, which is robust to model specification in terms of both magnitude and statistical significance. However, we do not observe any relationship with the book profit. This result indicates that speculation responds to derivatives cash flows but not to book profits. We then refine the specification to employ the selective hedging component of derivatives cash flows. From Table 4, we observe that the relationship between hedge ratio volatility and selective hedging cash flows is positive and significant, providing evidence in favor of the hypothesis that the success of past selective hedging leads to higher levels of speculation in the future. Again, we do not find a significant relationship with book profits. Nonetheless, speculation is also positively related to benchmark cash flows, which is consistent with our observation in Table 3 for total derivatives cash flows.

Given that the tests reported in Tables 3 and 4 were performed on a reduced sample, we next perform robustness checks to control for the possibility of selection bias by allowing for the two sequential decisions of the firm, (1) whether or not to use derivatives, and (2) conditional on being a derivatives user, how much to speculate. We estimate the two-step Heckman procedure with selection. In the first stage, we estimate a PROBIT model, where the dependent variable is equal to zero if (1) the firm has zero hedge ratios in both the beginning and the end of quarter t; or (2) the firm had zero cash flows from hedging operations in quarter t-1. ${ }^{16}$ We estimate the likelihood of derivatives usage as a function of several firm characteristics: size, market-to-book ratio, the ratio of book debt to book equity, quick ratio, dividend-payer status, existence of a credit rating, and Altman's Z-score. In the second stage, we estimate the relationship between hedge ratio volatility and past cash flows and book profits from derivatives positions conditional

\footnotetext{
${ }^{16} \mathrm{We}$ also run the first stage estimation using only the first condition (non-zero hedge ratios) to define hedging activity and obtain similar results. They are not reported due to space constraints but are available on request.
} 
on the firm being a derivatives user. The results from the two stages of the Heckman procedure are presented in Table 5 Panels A and B, respectively.

[Place Table 5 about here]

From Table 5 Panel A, we observe that firms that use derivatives are large firms with low growth opportunities (as indicated by low market-to-book ratios), conservative leverage policies, and higher financial constraints/low liquidity. These results are consistent with previously reported findings by Bodnar, Hayt and Marston (1998) and Haushalter (2000).

The Heckman second-stage results reported in Panel B are consistent with our previous findings reported in Tables 3 and 4. In all regression specifications, we observe a positive and significant relationship between hedge ratio volatility and past cash flows from derivatives positions (whether total derivatives cash flows or selective hedging cash flows) and benchmark cash flows. We observe no relationship between hedge ratio volatility and past book profits from derivatives positions.

\subsection{Accounting for asymmetry effects}

Having established the relation between speculation and derivatives cash flows, we now turn to our test for the presence of managerial overconfidence in our sample firms. We do so by examining the asymmetry in the relationship between derivatives cash flows and speculation. For this purpose, we run the following regression with dummy variables:

$$
V_{t}=a+b_{1} S C F_{t-1} \cdot I_{1}+b_{2} S C F_{t-1} \cdot I_{2}+\operatorname{CONTROLS}_{t}+\varepsilon_{t}
$$

In this regression, $I_{1}\left(I_{2}\right)$ is a dummy variable that equals one if the selective hedging cash flow during the last quarter was positive (negative) and zero otherwise. We choose selective hedging cash flow to be the dependent variable because selective hedging cash flow is the direct 
consequence of speculative decisions made by the manager in the past, and therefore is more directly related to the extent to which past speculation was successful than total cash flows. We include the benchmark cash flow, along with the firm characteristics, in the matrix of control variables. ${ }^{17}$

We estimate this regression first on a reduced sample of firm-quarters for active hedgers and next, using the Heckman two-step procedure for robustness. The results of the second-stage Heckman procedure with controls are presented in Table $6 .{ }^{18}$ While the asymmetric response of hedge ratio volatility to selective hedging cash flow persists in this alternative specification, the significance of the benchmark cash flow variable is diminished.

[Place Table 6 about here]

From Table 6, we observe that the relationship between hedge ratio volatility and past selective hedging cash flows is strongly positive only if the past selective hedging cash flows are positive. A one-standard deviation increase in selective hedging cash flow leads to a 0.2774 increase in the quarterly volatility of the one-year hedge ratio, which is $22.5 \%$ of the sample mean of 1.2325. When selective hedging cash flows are negative, however, we observe no significant relationship except in the case of one-year hedge ratio volatility. However, while we would still expect a positive coefficient for one-year hedge ratio volatility with negative selective hedging cash flows if the relation between speculation and selective hedging cash flow is symmetric (since speculation should decrease as speculation losses increase) this is the opposite of what we observe for one-year hedge ratio volatility.

\footnotetext{
${ }^{17}$ Nevertheless, we check robustness of the results to using total derivatives cash flow and find that the general result is similar in spirit although less significant. The results are not reported but are available upon request.

${ }^{18}$ The results of the panel regressions on the reduced sample are qualitatively similar to the Heckman regressions and are available on request.
} 
Given the centrality of the asymmetry result to the conclusions of our paper, we perform several robustness tests. First, we run a regression of hedge ratio volatility on selective hedging cash flow with asymmetry without controlling for the selection bias. Doing so is potentially important given that some of the variables chosen for the first stage of the Heckman regression may be endogenous and given also that in some of the models the Mills ratio is not significant. Table 7 shows the results, which are robust.

[Place Table 7 about here]

As an additional check, a Tobit regression may be important to control for the left-censoring problem given that we drop the observations where the volatility measure is zero. Consequently, we run a Tobit regression and again find robust asymmetry results as shown in Table 8 .

[Place Table 8 about here]

Lastly, instead of the hedge ratio volatility, we use a different measure to proxy for the extent of managerial speculation. Specifically, we rerun the asymmetry regression for the annual Cragg residual (averaged over four quarters), as the dependent variable. Cragg residuals are calculated as in Adam and Fernando (2006). As shown in Table 9, we confirm the asymmetry results for the Cragg residuals as well.

[Place Table 9 about here.]

Thus, our evidence in this section strongly supports an asymmetric relation between speculative activity and selective hedging cash flows, which confirms the managerial overconfidence hypothesis for our sample firms. Managers increase speculative activity following successes (as their overconfidence rises) but do not symmetrically reduce it following failures. This result is robust to the inclusion of firm characteristics that may affect the 
fundamental hedging needs of the firm, as well as to controlling for possible selection biases, endogenous firm characteristics, censoring, and choice of a specific speculation measure.

\subsection{Other robustness checks}

As discussed in Section 3.2, we perform a robustness check to control for managerial compensation. Table 10 Panels A and B present the results of the regressions of hedge ratio volatility on past cash flows while controlling for the managerial compensation variables (delta and vega) of the $\mathrm{CEO}$ and the $\mathrm{CFO}$. The regressions are univariate due to the limited number of managerial compensation observations in our sample. However, the regressions indicate that overall, our inference regarding the effect of derivatives cash flows on speculation remains unaffected while the managerial compensation variables are statistically insignificant.

\section{[Place Table 10 about here]}

In addition to controlling for the rational explanations as laid out in Section 3.2, we also perform a few more robustness checks. First, past cash flows as well as derivatives book profits may be related to movements in the price of gold over the same quarter. This concern is mitigated by the fact that derivatives cash flows are the result of hedging decisions taken in the distant past as well as more current decisions and therefore, the recent change in the price of gold may not have a strong effect. Additionally, this issue is much less of a concern for selective hedging cash flows, which is our main variable of interest. Nevertheless, in unreported tests we include the change in the price of gold in our regressions without a substantive effect on our results. In the two-stage Heckman framework, we also allow for the relationship between hedge ratio volatility and past selective hedging cash flows to be a function of the beginning-of-quarter hedge ratio. In these robustness tests, also available upon request, we continue to find that hedge 
ratio volatility is positively related to past derivatives cash flows and that the relationship is robustly stronger for positive selective hedging cash flows, consistent with our managerial overconfidence hypothesis.

While we control for liquidity and financial strength in our regressions, there may still be potential endogeneity if hedging positions affect the gains and losses, and these are serially correlated. In unreported results, we have explored whether our cash flow variable is indeed serially correlated, but found no supporting evidence. In particular, the Durbin-Watson h-test / ttest identifies no serial correlation for either total cash flow or benchmark cash flow; and no serial correlation in all but ten companies for selective cash flow. In addition, we believe that our main finding is the asymmetry in the relationship between derivatives cash flows and speculation, i.e., the volatility of hedge ratio responds only to positive cash flow but not to negative cash flow. In the case of an endogenous effect of cash flow on hedging activities, it is difficult to argue that the effect should be asymmetrical.

\subsection{Other measures of overconfidence}

The extant literature has identified several corporate behaviors as ones potentially affected by managerial overconfidence, among them acquisitiveness (Malmendier and Tate (2008); Billett and Qian (2008)). Hence, we consider the activity of our sample firms on the M\&A market as a potential cross-sectional proxy for overconfidence. Table 11, Panel A shows the descriptive statistics of the merger and acquisition activity of the firms in our sample. The data is from the SDC database. Over our sample period, the median firm attempted around five acquisitions of which, on average, 60 percent were successful, which suggests considerable activity on the 
M\&A market. The acquisition size is also considerable, with the fraction of the target firm sought being 68 percent on average.

[Place Table 11 about here]

Table 11, Panel B shows the correlations between M\&A activity and other firm characteristics including our measure of selective hedging, the hedge ratio volatility. We use one-year hedge ratio volatility for this purpose. We also chose to use the number of attempted (as opposed to completed) deals as a measure of activity; however when we use completed deals the results are very similar. Several observations emerge from this table. First, firms with more attempted acquisitions tend to be larger and more stable firms as indicated by the positive correlation coefficients with size, dividends, and rating. However, firms that engage more in selective hedging tend to be, on the contrary, smaller and less financially stable firms as indicated by the negative correlation coefficients with Z-score. Moreover, the direct correlation between attempted merger deals and selective hedging is negative. The evidence suggests that the activity on the M\&A market is related to fundamental firm characteristics in a way that makes acquisitiveness an unlikely candidate for measuring overconfidence in our data pertaining specifically to hedging behavior.

To take a closer look at the relationship between M\&A and fundamental firm characteristics we run an OLS regression of the number of attempted deals on size, leverage, liquidity and other characteristics as presented in Table 11, Panel C. Once again, it emerges from the table that firms that are more active on the M\&A market are larger and more stable firms with lower debt and higher liquidity, i.e., the firms that are less likely to engage in selective hedging. 
We also examine managerial option compensation, since the extant literature has identified option holdings as a measure of overconfidence (Malmendier and Tate (2005)). As evident from Panel B of Table 12, however, we find results for option compensation that are similar to those for M\&A activity from the standpoint of managerial overconfidence in hedging practices -- firms that compensate their CEO or CFO with options to a greater extent, if anything, are less engaged in selective hedging. The evidence is similar if option compensation is scaled by size (not reported but available upon request). It is unlikely therefore, that option compensation would make for a good measure of overconfidence in our sample.

[Place Table 12 about here]

In summary, our findings in this section suggest that neither measures of acquisitiveness nor option compensation would serve as good cross-sectional proxy variables for overconfidence in our hedging data. On the other hand, our previous results using time series data that clearly point to overconfidence in our sample highlight the importance of using both cross-sectional and time series approaches to detect overconfidence, and the complementarity of the two approaches.

\section{Conclusions}

We add to the growing literature that documents the influence of managerial overconfidence in a variety of corporate settings, including investment and capital structure policy, innovation, mergers and acquisitions, security offerings, and investment bank relationships, by showing that the effect of overconfidence also extends to corporate hedging decisions. We document a positive relationship between speculation and past speculative gains, without a corresponding relation between speculation and past speculative losses. This asymmetry supports the conjecture that the financial success of past speculative decisions increases managerial overconfidence, 
leading managers to elevate their levels of speculation, while losses do not reduce managerial overconfidence because managers tend to attribute failures to bad luck. Our findings provide evidence that corporate risk management practices are affected by behavioral managerial biases, and suggest that recognizing the presence of these biases will help bridge the gap between the theory and practice of corporate risk management. 


\section{Appendix 1: Variable Notations and Definitions}

Hedge Ratios:

HR1 - HR5 are the hedge ratios from one- to five-year maturities, respectively;

A3 is the aggregate hedge ratio that aggregates the hedge positions over one-, two-, and threeyear horizons, scaled by the expected production;

A3R is the aggregate hedge ratio that aggregates the hedge positions over one-, two-, and threeyear horizons, scaled by gold reserves;

A5R is the aggregate hedge ratio that aggregates the hedge positions over one-, two-, three-, four- and five-year horizons, scaled by gold reserves.

Hedge Ratio Volatility:

V1 - V5 are the quarterly volatilities of the one- through five-year hedge ratios, respectively.

Quarterly volatility is the absolute value of the difference in the natural logarithms of the end-ofquarter and beginning-of-quarter hedge ratio levels.

V6 - V8 are the corresponding quarterly volatilities for A3, A3R, and A5R, respectively.

Derivatives Cash Flows:

CF are the total cash flows from derivatives positions (in $\$$ per ounce hedged) estimated as in Adam and Fernando (2006);

SCF and BCF are the selective and the benchmark cash flows, estimated as in Adam and Fernando (2006);

RBK is the change in the book value of the derivatives positions per ounce hedged (see Appendix 2).

Firm Characteristics:

SIZ is the logarithm of the market value of assets (\$ million); 
MB is the market-to-book ratio of assets;

DE is the ratio of book debt to book equity;

QCK is the quick ratio;

DIV is a dummy variable equal to one if the firm paid quarterly dividend;

RAT is a dummy variable equal to one if a firm reports a credit rating;

$\mathbf{Z}$ is the Altman's (1968) Z-score (higher value of $Z$ corresponds to lower probability of bankruptcy).

DELTA_CEO (CFO) is the change in the dollar value of the CEO's (CFO's) wealth derived from ownership of stock and stock options in the firm when the firm's stock price changes by one percent, calculated according to the methodology of Core and Guay (2002). We calculate the aggregate delta of the executive's compensation as the sum of the deltas of the options holdings and the delta of the stock holdings.

VEGA_CEO (CFO) is the change in the dollar value of the CEO's (CFO's) wealth derived from ownership of stock and stock options in the firm when the annualized standard deviation of the firm's stock price changes by 0.01 , following Core and Guay (2002). We calculate the aggregate vega of the executive's compensation as the sum of the vegas of the executive's options holdings, following Coles, Daniel and Naveen (2006).

GLD is the change in the price of gold over the quarter; 


\section{Appendix 2: Calculation of Quarterly Derivatives Book Profits}

For the calculations of derivatives book profits, we use delta of the linear positions (which is equal to -1) and delta of option positions, which we back out from the total delta of the firm. We calculate the delta of option positions at the end of the quarter as the firm's total delta plus the number of linear contracts:

$$
\Delta_{t, \text { Option }}=\Delta_{t, \text { Total }}+N_{t, \text { Forward }}+N_{t, \text { Spot }}+N_{t, \text { Loan }}
$$

In (A1), $\Delta_{t, \text { Total }}$ is the total delta of the firm, $N_{t, \text { Forward }}$ is the number of forward contracts, $N_{t, \text { Spot }}$ is the number of spot contracts, and $N_{t, \text { Loan }}$ is the number of loan contracts. Then, for each quarter, we calculate the minimum of the two hedge positions,

$$
\begin{aligned}
& \operatorname{MIN}_{N L I N, t}=\min \left(N_{t, \text { Linear }}, N_{t-1, \text { Linear })}\right. \\
& M I N_{N O P T, t}=\min \left(N_{t, \text { Option }}, N_{t-1, \text { Option })}\right.
\end{aligned}
$$

Above, $\operatorname{MIN}_{N L I N, t}$ is the smaller of the beginning-of-quarter and end-of-quarter linear positions (forward plus spot plus loan) and $M I N_{N O P T, t}$ is the smaller of the beginning-of-quarter and end-ofquarter option positions. Obviously, at this step we lose observations where the size of the position is missing either at the beginning or at the end of the quarter.

Next, we calculate the delta $M \Delta_{t, \text { Option }}$ of option positions as the beginning-of-quarter delta $\Delta_{t-1, \text { Option }}$, divided by the beginning-of-quarter option position $N_{t-1, \text { Option }}$, multiplied by the smaller of the beginning-of-quarter and the end-of-quarter positions:

$$
M \Delta_{t, \text { Option }}=\Delta_{t-1, \text { Option }} \cdot M I N_{N O P T, t} / N_{t-1, \text { Option }}
$$

If both option positions $N_{, t, \text { Option }}$ and $N_{t-1, \text { Option }}$ are zero, then delta is set to zero. Next, we use the option delta $M \Delta_{t, \text { Option }}$ to calculate the total book profits from linear positions $B K_{t, \text { Linear }}$, from option positions $B K_{t, \text { Option, }}$, and from all positions $B K_{t}$, where $G O L D_{t}$ is the price of one ounce of gold at the end of quarter $t$ : 


$$
\begin{gathered}
B K_{t, \text { Linear }}=M I N_{N L I N, t} \cdot\left(G O L D_{t-1}-G O L D_{t}\right) \\
B K_{t, \text { Option }}=M \Delta_{t, \text { Option }} \cdot\left(G O L D_{t-1}-G O L D_{t}\right) \cdot(-1) \\
B K_{t}=B K_{t, \text { Linear }}+B K_{t, \text { Option }}
\end{gathered}
$$

Finally, to adjust for the scale effect, we scale the total profits by the average size of the firm's position to obtain relative book profits from option positions $R B K_{t, \text { Option }}$, from linear positions $R B K_{t, \text { Linear }}$, and from all positions $R B K_{t,}$. The average size of the linear position $\bar{N}_{\text {Linear }}$ is equal to the average number of linear contracts reported by the firm over all quarters of the sample period in which a non-zero linear position is reported. The average size of the option positions $\bar{N}_{\text {Option }}$ is computed similarly.

$$
\begin{aligned}
& R B K_{t, \text { Option }}=B K_{t, \text { Option }} / \bar{N}_{\text {Option }} \\
& R B K_{t, \text { Linear }}=B K_{t, \text { Linear }} / \bar{N}_{\text {Linear }} \\
& R B K_{t}=R B K_{t, \text { Linear }}+R B K_{t, \text { Option }}
\end{aligned}
$$




\section{References}

Adam, Tim, and Chitru Fernando, 2006, Hedging, Speculation, and Shareholder Value, Journal of Financial Economics 81, 283-309.

Adams, Mike, Chen Lin, and Hong Zou, 2011, Chief Executive Officer Incentives, Monitoring, and Corporate Risk Management: Evidence from Insurance Use, Journal of Risk and Insurance $78,551-582$.

Allayannis, George, and James P. Weston, 2001, The Use of Foreign Currency Derivatives and Firm Market Value, Review of Financial Studies 14, 243-276.

Alizadeh, Sassan, Michael W. Brandt, and Francis X. Diebold, 2002, Range-Based Estimation of Stochastic Volatility Models, Journal of Finance 57, 1047-1092.

Altman, Edward I., 1968, Financial Ratios, Discriminant Analysis and the Prediction of Corporate Bankruptcy, Journal of Finance 23, 589-609.

Ang, Andrew, Robert J. Hodrick, Yuhang Xing, and Xiaoyan Zhang, 2006, The Cross-Section of Volatility and Expected Returns, Journal of Finance 61, 259-299.

Ang, James, and Nathan Mauck, 2011, Fire Sale Acquisitions: Myth vs. Reality, Journal of Banking \& Finance 35, 532-543.

Baker, Malcolm, Richard S. Ruback, and Jeffrey Wurgler, 2007, Behavioral Corporate Finance: A Survey, in The Handbook of Corporate Finance: Empirical Corporate Finance, edited by Espen Eckbo. Elsevier/North Holland, New York.

Barber, Brad M., and Terrance Odean, 2000, Trading is Hazardous to Your Wealth: The Common Stock Investment Performance of Individual Investors, Journal of Finance 55, 773806.

Ben-David, Itzhak, John R. Graham, and Campbell R. Harvey, 2013, Managerial Miscalibration, Quarterly Journal of Economics 128: 1547-1584.

Billett, Matthew T., and Yiming Qian, 2008, Are Overconfident CEOs Born or Made? Evidence of Self-Attribution Bias from Frequent Acquirers, Management Science 54, 1037-1051.

Bodnar, Gordon N., Gregory S. Hayt, and Richard C. Marston, 1998, Wharton Survey of Derivatives Usage by U.S. Non-Financial Firms, Financial Management 27, 70-91.

Breeden, Douglas, and S. Viswanathan, 1998, Why Do Firms Hedge? An Asymmetric Information Model, Working Paper.

Brown, Gregory W., Peter R. Crabb, and David Haushalter, 2006, Are Firms Successful at Selective Hedging? Journal of Business, 79, 2925-2949.

Campbell, Tim S. and William A. Kracaw, 1999, Optimal Speculation in the Presence of Costly External Financing. In "Corporate Risk: Strategies and Management," Gregory Brown and Donald Chew, editors, Risk Publications, London. 
Campello, Murillo, Chen Lin, Yue Ma, and Hong Zou, 2011, The Real and Financial Implications of Corporate Hedging, Journal of Finance 66, 1615 - 1647.

Daniel, Kent D., David Hirshleifer, and Avanidhar Subrahmanyam, 1998, Investor Psychology and Security Market Under- and Over-Reactions, Journal of Finance 53, 1839 - 1867.

DeMarzo, Peter M. and Darrell Duffie, 1995, Corporate Incentives for Hedging and Hedge Accounting, Review of Financial Studies 8, $743-772$.

Dolde, Walter, 1993, The Trajectory of Corporate Financial Risk Management, Journal of Applied Corporate Finance 6, 33-41.

Fehle, Frank, and Sergey Tsyplakov, 2005, Dynamic Risk Management: Theory and Evidence, Journal of Financial Economics 78, 3-47.

Froot, Kenneth.A., David S. Scharfstein, and Jeremy C. Stein, 1993, Risk Management: Coordinating Corporate Investment and Financing Policies, Journal of Finance 48, 1629 - 1658.

Géczy, Christopher C., Bernadette A. Minton, and Catherine Schrand, 2007, Taking a View: Corporate Speculation, Governance and Compensation, Journal of Finance 62, 2405 - 2443.

Gervais, Simon, J.B. Heaton, and Terrance Odean, 2009, Overconfidence, Compensation Contracts, and Capital Budgeting, Journal of Finance 66, 1735 - 1777.

Gervais, Simon, and Terrance Odean, 2001, Learning to be Overconfident, Review of Financial Studies 14, 1-27.

Glaum, Martin, 2002, The Determinants of Selective Exchange-Risk Management - Evidence from German Non-Financial Corporations, Journal of Applied Corporate Finance 14, 108 - 121.

Goel, Anand, and Anjan Thakor, 2008, Overconfidence, CEO Selection and Corporate Governance, Journal of Finance 63, 2737- 2784.

Griffin, Dale and Amos Tversky, 1992, The Weighing of Evidence and the Determinants of Confidence, Cognitive Psychology 24, 411-435.

Grundy, Bruce D., and Hui Li, 2010, Investor Sentiment, Executive Compensation, and Corporate Investment, Journal of Banking \& Finance 34, 2439-2449.

Haushalter, G. David, 2000, Financing Policy, Basis Risk, and Corporate Hedging: Evidence from Oil and Gas Producers, Journal of Finance 55, 107 - 152.

Heaton, J.B., 2002, Managerial Optimism and Corporate Finance, Financial Management, Summer, 33-45.

Heckman, James J., 1979, Sample Selection as a Specification Error, Econometrica 47, 153 161.

Jaggia, Sanjiv, and Satish Thosar, 2006, The Medium-Term Aftermarket in High-Tech IPOs: Patterns and Implications, Journal of Banking \& Finance 28, 931-950. 
Jin, Yanbo, and Philippe Jorion, 2006, Firm Value and Hedging: Evidence from U.S. Oil and Gas Producers, Journal of Finance 61, 893 - 919.

Leland, Hayne E., 1998, Agency Costs, Risk Management, and Capital Structure, Journal of Finance 53, 1213-1243.

Ljungqvist, Alexander, and William J. Wilhelm, Jr., 2005, Does Prospect Theory Explain IPO Market Behavior? Journal of Finance 60, 1759-1790.

Loughran, Tim, and Jay R. Ritter, 2002, Why Don't Issuers Get Upset About Leaving Money on the Table in IPOs? Review of Financial Studies 15, 413-443.

Malmendier, Ulrike, and Geoffrey Tate, 2005, CEO Overconfidence and Corporate Investment, Journal of Finance 60, 2661 - 2700.

Malmendier, Ulrike, and Geoffrey Tate, 2008, Who Makes Acquisitions? CEO Overconfidence and the Market's Reaction, Journal of Financial Economics 89, 20-43.

Malmendier, Ulrike, Geoffrey Tate, and Jon Yan, 2011, Overconfidence and Early-life Experience: The Effect of Managerial Traits on Corporate Financial Policies, Journal of Finance 66, $1687-1733$.

Neupane, Suman, and Sunil S. Poshakwale, 2012, Transparency in IPO Mechanism: Retail Investors' Participation, IPO Pricing and Returns, Journal of Banking \& Finance 36, 2064-2076.

Mello, Antonio, and John Parsons, 2000, Hedging and Liquidity, Review of Financial Studies 13, $127-153$.

Miller, Dale T., and Michael Ross, 1975, Self-Serving Biases in the Attribution of Causality: Fact or Fiction? Psychological Bulletin 82, 213-225.

Roll, Richard, 1986, The Hubris Hypothesis of Corporate Takeovers, Journal of Business 59, 197-216.

Russo, J. Edward, and Paul J.H. Schoemaker, 1992, Managing Overconfidence, Sloan Management Review 33, 7-17.

Sautner, Zacharias, and Martin Weber, 2009, How Do Managers Behave in Stock Option Plans? Clinical Evidence from Exercise and Survey Data, Journal of Financial Research 32, 123-155.

Smith, Clifford W., and Rene M. Stulz, 1985, The Determinants of Firms' Hedging Policies, Journal of Financial and Quantitative Analysis 20, 391-405.

Stulz, René M., 1984, Optimal Hedging Policies, Journal of Financial and Quantitative Analysis $19,127-140$.

Stulz, René M., 1996, Rethinking Risk Management, Journal of Applied Corporate Finance 9, 8-24.

Tufano, Peter, 1996, Who Manages Risk? An Empirical Examination of Risk Management Practices in the Gold Mining Industry, Journal of Finance 51, 1097-1137. 
Tufano, Peter, 1998. The Determinants of Stock Price Exposure: Financial Engineering and the Gold Mining Industry, Journal of Finance 53, 1051-1052.

Working, Holbrook, 1962, New Concepts Concerning Futures Markets and Prices, American Economic Review 52, 431 - 459. 


\section{Table 1}

\section{Descriptive Statistics of Hedge Ratios, Hedge Volatility, Cash Flows, and Firm Characteristics}

Descriptive statistics are estimated on the pooled dataset. The sample consists of quarterly observations from 19891999 for a sample of 92 North American gold mining firms as reported in Gold and Silver Hedge Outlook. The table reports summary statistics for the following variables: hedge ratios of various maturities as well as aggregate hedge ratios estimated as the sum of the firm's derivatives positions in place in quarter $t$ (in ounces of gold), weighted by their respective deltas, scaled either by expected production or by reserves; hedge ratio volatilities estimated as the absolute value of the ratio of natural logarithms of the end-of-quarter to the beginning-of-quarter hedge ratio; total cash flows from derivatives positions per ounce hedged as well as selective and benchmark cash flows, which are estimated as in Adam and Fernando (2006); derivatives book profit equal to the change in the book value of the derivatives positions per ounce hedged (see Appendix 2 for calculation); change in the price of gold per ounce; firm size measured as the logarithm of the market value of assets; market-to-book ratio of assets; ratio of book debt to book equity; quick ratio; dividend dummy variable equal to one if the firm paid quarterly dividend; credit rating dummy variable equal to one if a firm reports a credit rating; and Altman's (1968) Z-score. Firm characteristics are from Compustat.

\begin{tabular}{|c|c|c|c|c|c|c|}
\hline \multirow[t]{2}{*}{ Variable } & & \multirow[t]{2}{*}{ Mean } & \multirow{2}{*}{$\begin{array}{l}\text { Standard } \\
\text { Deviation } \\
\end{array}$} & \multirow[t]{2}{*}{ Minimum } & \multirow[t]{2}{*}{ Maximum } & \multirow{2}{*}{$\begin{array}{c}\text { Number of } \\
\text { Observations }\end{array}$} \\
\hline & & & & & & \\
\hline \multicolumn{2}{|c|}{ One-year hedge ratio } & 0.2874 & 0.3179 & 0.0000 & 1.0000 & 1875 \\
\hline \multicolumn{2}{|c|}{ Two-year hedge ratio } & 0.1552 & 0.2418 & 0.0000 & 1.0000 & 1879 \\
\hline \multicolumn{2}{|c|}{ Three-year hedge ratio } & 0.0779 & 0.1722 & 0.0000 & 1.0000 & 1901 \\
\hline \multicolumn{2}{|c|}{ Four-year hedge ratio } & 0.0363 & 0.1135 & 0.0000 & 1.0000 & 1935 \\
\hline \multicolumn{2}{|c|}{ Five-year hedge ratio } & 0.0271 & 0.1092 & 0.0000 & 0.9990 & 1952 \\
\hline \multicolumn{2}{|c|}{ Aggregate 3-yr. ratio, prod. } & 0.1716 & 0.2402 & 0.0000 & 1.0000 & 1460 \\
\hline \multicolumn{2}{|c|}{ Aggregate 3-yr. ratio, res. } & 0.0465 & 0.0738 & 0.0000 & 0.6620 & 1460 \\
\hline \multicolumn{2}{|c|}{ Aggregate 5-yr. ratio, res. } & 0.0575 & 0.0961 & 0.0000 & 0.9857 & 1460 \\
\hline \multicolumn{2}{|c|}{ Volatiliy, 1-yr. ratio } & 1.2325 & 2.9044 & 0.0000 & 12.4055 & 1665 \\
\hline \multicolumn{2}{|c|}{ Volatility, 2-yr. ratio } & 1.2304 & 2.9902 & 0.0000 & 12.7594 & 1660 \\
\hline \multicolumn{2}{|c|}{ Volatility, 3-yr. ratio } & 0.8524 & 2.5275 & 0.0000 & 11.5129 & 1694 \\
\hline \multicolumn{2}{|c|}{ Volatility, 4yr. ratio } & 0.8324 & 2.5702 & 0.0000 & 11.5129 & 1732 \\
\hline \multicolumn{2}{|c|}{ Volatility, 5-yr. ratio } & 0.5135 & 2.0428 & 0.0000 & 11.4742 & 1761 \\
\hline \multicolumn{2}{|c|}{ Volatility, 3-yr. agg. ratio, prod. } & 0.6838 & 2.0897 & 0.0000 & 11.5000 & 1253 \\
\hline \multicolumn{2}{|c|}{ Volatility, 3-yr. agg. ratio, res. } & 0.6477 & 1.8500 & 0.0000 & 10.5740 & 1262 \\
\hline \multicolumn{2}{|c|}{ Volatility, 5-yr. agg. ratio, res. } & 0.6867 & 1.8970 & 0.0000 & 11.2149 & 1304 \\
\hline \multicolumn{2}{|c|}{ Total derivative cash flow } & 4.8063 & 16.2041 & -95.9039 & 180.1249 & 1788 \\
\hline \multicolumn{2}{|c|}{ Selective cash flow } & 0.3680 & 10.5898 & -66.7713 & 201.8647 & 1801 \\
\hline \multicolumn{2}{|c|}{ Benchmark cash flow } & 4.4377 & 16.7540 & -90.4059 & 180.1249 & 1788 \\
\hline \multicolumn{2}{|c|}{ Derivative book profit } & 2.1401 & 16.4882 & -181.3730 & 106.0881 & 1750 \\
\hline \multicolumn{2}{|c|}{ Change in the price of gold } & -3.0569 & 17.7753 & -48.9000 & 52.0000 & 1781 \\
\hline Size & & 5.5771 & 1.7608 & 1.0460 & 9.3604 & 1858 \\
\hline \multicolumn{2}{|c|}{ Market-to-Book ratio } & 1.9381 & 1.1137 & 0.2985 & 9.0819 & 1647 \\
\hline \multicolumn{2}{|c|}{ Debt-to-Equity ratio } & 0.4619 & 1.0772 & 0.0000 & 21.2707 & 1205 \\
\hline Quick ratio & & 4.2476 & 9.7254 & 0.0065 & 141.5172 & 1161 \\
\hline \multicolumn{2}{|c|}{ Dividend dummy } & 0.4701 & 0.4993 & 0.0000 & 1.0000 & 1289 \\
\hline \multicolumn{2}{|c|}{ Rating dummy } & 0.2454 & 0.4305 & 0.0000 & 1.0000 & 1312 \\
\hline Altman's Z & score & 4.9900 & 13.5111 & -22.8560 & 126.8310 & 1618 \\
\hline
\end{tabular}


Table 2

\section{Correlations across Hedge Ratios and across Hedge Ratio Volatilities}

Correlations are estimated on the pooled dataset. The sample consists of quarterly observations over 1989-1999 for a sample of 92 North American gold mining firms as reported in Gold and Silver Hedge Outlook. HR1 - HR5 are hedge ratios with one- to five- year maturity, respectively; VI - V5 are their respective volatilities; $A 3$ is the aggregate 3-year hedge ratio scaled by expected production, $A 3 R$ is the aggregate 3-year hedge ratio scaled by reserves, and $A 5 R$ is the aggregate five-year hedge ratio scaled by reserves, and $V 6-V 8$ are their respective volatilities. ${ }^{* * *}, * *$, and $*$ indicate significance at $1 \%, 5 \%$, and $10 \%$ level, respectively.

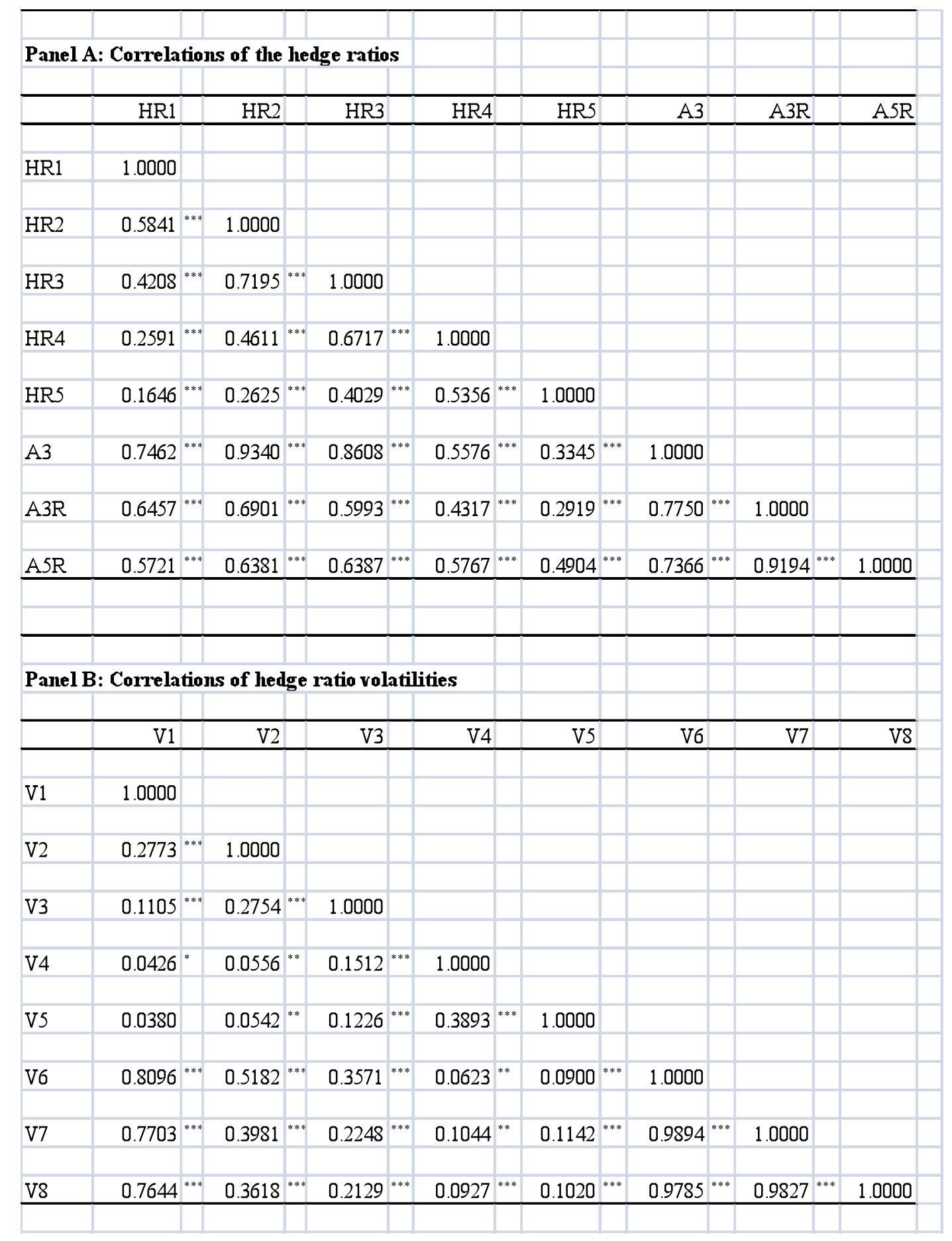


Table 3

\section{Relationship between Speculation and Past Total Derivatives Cash Flows}

The table presents the results of the panel regressions with firm fixed effects. The dependent variable is the volatility of the hedge ratio. Hedge ratio volatility is estimated as the absolute value of the difference in the logs of the hedge ratio in the end and the beginning of the quarter. The independent variables are as follows: $C F$ is the total derivatives cash flow in the previous quarter; $R B K$ is the change in the book value of derivatives positions in the previous quarter. Seasonal dummies are included in each of the models. The regressions include the following firm characteristics as control variables: $S I Z$, firm size measured as the logarithm of the market value of assets; $M B$, market-to-book ratio of assets; $D E$, ratio of book debt to book equity; $Q C K$, quick ratio; $D I V$, dummy variable equal to one if the firm paid quarterly dividend; $R A T$, dummy variable equal to one if a firm reports a credit rating; and $Z$, Altman's Z-score. $* * *, * *, *$ indicate significance at the $1 \%, 5 \%$ and $10 \%$ levels, respectively. Robust t-statistics corrected for cluster effects are reported in parentheses.

\begin{tabular}{|c|c|c|c|c|c|c|c|c|}
\hline & \multicolumn{2}{|c|}{ Volatility of } & \multicolumn{2}{|c|}{ Volatility of } & \multicolumn{2}{|c|}{ Volatility of } & \multicolumn{2}{|c|}{ Volatility of } \\
\hline & \multirow{2}{*}{\multicolumn{2}{|c|}{ one-year hedge ratio }} & \multirow{2}{*}{\multicolumn{2}{|c|}{$\begin{array}{l}\text { aggregate 3-year ratio } \\
\text { scaled by production }\end{array}$}} & \multirow{2}{*}{\multicolumn{2}{|c|}{$\begin{array}{l}\text { aggregate } 3 \text {-year ratio } \\
\text { scaled by reserves }\end{array}$}} & \multirow{2}{*}{\multicolumn{2}{|c|}{$\begin{array}{l}\text { aggregate } 5 \text {-year ratio } \\
\text { scaled by reserves }\end{array}$}} \\
\hline & & & & & & & & \\
\hline & (1) & (2) & (3) & (4) & (5) & (ด) & (7) & (8) \\
\hline \multirow[t]{2}{*}{ Intercept } & $0.9315^{* * *}$ & 2.9375 & $0.7202^{* * *}$ & $3.7069^{*}$ & $0.6400^{* * *}$ & 1.6145 & $0.7448^{* * *}$ & 1.2300 \\
\hline & $(5.29)$ & $(1.10)$ & $(5.40)$ & (1.93) & $(4.75)$ & $(0.80)$ & $(6.40)$ & (0.77) \\
\hline \multirow[t]{2}{*}{ CF } & $0.023^{* * *}$ & $0.0181 * *$ & $0.0213^{* * *}$ & 0.0113 & $0.0237^{* * *}$ & $0.0209^{* * *}$ & $0.0164^{* * *}$ & $0.0150^{* *}$ \\
\hline & $(3.60)$ & $(2.24)$ & (3.03) & (1.53) & (3.54) & $(2.95)$ & (3.53) & $(2.89)$ \\
\hline \multirow[t]{2}{*}{ RBK } & 0.0019 & -0.0017 & -0.0011 & -0.0017 & -0.0020 & -0.0038 & -0.0003 & -0.0021 \\
\hline & (0.91) & $(-0.72)$ & $(-0.69)$ & $(-0.74)$ & $(-1.29)$ & $(-1.68)$ & $(-0.23)$ & $(-0.97)$ \\
\hline \multirow[t]{2}{*}{ SIZ } & & -0.1817 & & -0.3584 & & -0.0319 & & 0.0572 \\
\hline & & $(-0.39)$ & & $(-1.18)$ & & $(-0.09)$ & & $(0.20)$ \\
\hline \multirow[t]{2}{*}{$Z$} & & 0.0730 & & 0.0787 & & 0.0458 & & $0.0490^{*}$ \\
\hline & & $(1.30)$ & & $(1.64)$ & & $(1.29)$ & & $(1.91)$ \\
\hline \multirow[t]{2}{*}{ QCK } & & 0.0212 & & -0.0208 & & -0.0342 & & -0.0127 \\
\hline & & $(0.27)$ & & $(-0.57)$ & & $(-1.24)$ & & $(-0.44)$ \\
\hline \multirow[t]{2}{*}{ MB } & & $-0.5594^{* * *}$ & & -0.2617 & & -0.2153 & & $-0.2190^{*}$ \\
\hline & & $(-2.64)$ & & $(-1.70)$ & & $(-1.53)$ & & $(-1.98)$ \\
\hline \multirow[t]{2}{*}{$\mathrm{DE}$} & & -0.1862 & & -0.2467 & & $-0.4726^{* * *}$ & & $-0.3233^{*}$ \\
\hline & & $(-1.12)$ & & $(-1.28)$ & & $(-4.40)$ & & $(-2.32)$ \\
\hline \multirow[t]{2}{*}{ DIV } & & 0.2905 & & -0.2261 & & -0.2401 & & -0.6023 * \\
\hline & & (0.68) & & $(-0.70)$ & & $(-1.07)$ & & $(-3.52)$ \\
\hline \multirow[t]{2}{*}{ RAT } & & -0.3583 & & -0.0684 & & -0.1324 & & -0.2063 \\
\hline & & $(-0.68)$ & & $(-0.19)$ & & $(-0.43)$ & & $(-0.77)$ \\
\hline Dummies & YES & YES & YES & YES & YES & YES & YES & YES \\
\hline $\mathrm{R}^{2}$ & 0.0304 & 0.0382 & 0.0263 & 0.0330 & 0.0379 & 0.0519 & 0.0204 & 0.0364 \\
\hline F-statistic & 4.70 & 1.62 & 3.85 & 1.64 & 3.44 & 5.82 & 3.27 & 2.84 \\
\hline Observations & 1112 & 638 & 788 & 465 & 854 & 529 & 1005 & 621 \\
\hline Clusters & 84 & 65 & 65 & 48 & 61 & 51 & 63 & 53 \\
\hline & & & & & & & & \\
\hline
\end{tabular}




\section{Table 4}

\section{Relationship between Speculation and Past Selective Hedging Cash Flows}

The table presents the results of the panel regressions with firm fixed effects. The dependent variable is the volatility of the hedge ratio. Hedge ratio volatility is estimated as the absolute value of the difference in the logs of the hedge ratio in the end and the beginning of the quarter. The independent variables are as follows: $S C F$ is the selective hedging cash flow in the previous quarter; $B C F$ is the benchmark cash flow in the previous quarter; $R B K$ is the change in the book value of derivatives positions in the previous quarter. Seasonal dummies are included in each of the models. The regressions include the following firm characteristics as control variables: SIZ, firm size measured as the logarithm of the market value of assets; $M B$, market-to-book ratio of assets; $D E$, ratio of book debt to book equity; $Q C K$, quick ratio; $D I V$, dummy variable equal to one if the firm paid quarterly dividend; $R A T$, dummy variable equal to one if a firm reports a credit rating; and $Z$, Altman's Z-score. ***,**,* indicate significance at the $1 \%, 5 \%$ and $10 \%$ levels, respectively. Robust t-statistics corrected for cluster effects are reported in parentheses.

\begin{tabular}{|c|c|c|c|c|c|c|c|c|}
\hline & \multicolumn{2}{|c|}{ Volatility of } & \multicolumn{2}{|c|}{ Volatility of } & \multicolumn{2}{|c|}{ Volatility of } & \multicolumn{2}{|c|}{ Volatility of } \\
\hline & \multicolumn{2}{|c|}{ one-year hedge ratio } & \multicolumn{2}{|c|}{ aggregate 3-year ratio } & \multicolumn{2}{|c|}{ aggregate 3-year ratio } & \multicolumn{2}{|c|}{ aggregate 5-year ratio } \\
\hline & & & \multicolumn{2}{|c|}{ scaled by production } & \multicolumn{2}{|c|}{ scaled by reserves } & \multicolumn{2}{|c|}{ scaled by reserves } \\
\hline & (1) & (2) & (3) & (4) & $(5)$ & (0) & (7) & (8) \\
\hline \multirow[t]{2}{*}{ Intercept } & $0.9468^{* * *}$ & 2.9597 & $0.7154^{* * *}$ & $3.9226^{* *}$ & $0.63011^{* * *}$ & 1.7182 & $0.7338^{* * *}$ & 1.3219 \\
\hline & $(5.50)$ & (1.11) & $(5.39)$ & (2.02) & $(4.65)$ & $(0.84)$ & (6.31) & $(0.82)$ \\
\hline \multirow[t]{2}{*}{ SCF } & $0.0174 *$ & 0.0199 & $0.0237^{* * *}$ & $0.0210^{* *}$ & $0.0273^{* *}$ & $0.0263^{* *}$ & $0.0202^{* * *}$ & $0.0212^{* *}$ \\
\hline & $(1.60)$ & (1.54) & $(2.97)$ & $(2.80)$ & (3.43) & $(3.45)$ & (3.14) & (3.02) \\
\hline \multirow[t]{2}{*}{$\mathrm{BCF}$} & $0.0249^{* * *}$ & $0.0173^{* *}$ & $0.0209^{* * *}$ & 0.0092 & $0.02244^{* *}$ & $0.0180^{* *}$ & $0.0153^{* * *}$ & $0.0124^{* *}$ \\
\hline & (3.50) & $(2.15)$ & (2.95) & $(1.20)$ & (3.39) & $(2.50)$ & (3.40) & (2.49) \\
\hline \multirow[t]{2}{*}{ RBK } & 0.0021 & -0.0117 & -0.0012 & -0.0020 & -0.0021 & -0.0040 & -0.0004 & -0.0023 \\
\hline & $(0.90)$ & $(-0.73)$ & $(-0.72)$ & $(-0.80)$ & $(-1.30)$ & $(-1.77)$ & $(-0.30)$ & $(-1.08)$ \\
\hline \multirow[t]{2}{*}{$\operatorname{SIZ}$} & & -0.1851 & & -0.3901 & & -0.0454 & & 0.0413 \\
\hline & & $(-0.40)$ & & $(-1.28)$ & & $(-0.13)$ & & (0.14) \\
\hline \multirow[t]{2}{*}{$Z$} & & 0.0736 & & 0.0825 & & 0.0493 & & $0.0514^{* *}$ \\
\hline & & $(1.37)$ & & $(1.70)$ & & $(1.30)$ & & (1.90) \\
\hline \multirow[t]{2}{*}{ QCK } & & 0.0205 & & -0.0239 & & -0.0382 & & -0.0156 \\
\hline & & $(0.20)$ & & $(-0.65)$ & & $(-1.39)$ & & $(-0.54)$ \\
\hline \multirow[t]{2}{*}{ MB } & & -0.5615 & & -0.2738 & & -0.2282 & & $-0.2202^{* *}$ \\
\hline & & $(-2.64)$ & & $(-1.87)$ & & $(-1.64)$ & & $(-2.00)$ \\
\hline \multirow[t]{2}{*}{$\mathrm{DE}$} & & -0.1871 & & -0.2505 & & $-0.4789^{* *}$ & & $-0.3268^{* *}$ \\
\hline & & $(-1.12)$ & & $(-1.31)$ & & $(-4.65)$ & & $(-2.30)$ \\
\hline \multirow[t]{2}{*}{ DIV } & & 0.2899 & & -0.2042 & & -0.2401 & & -0.5993 \\
\hline & & $(0.68)$ & & $(-0.67)$ & & $(-1.10)$ & & $(-3.58)$ \\
\hline \multirow[t]{2}{*}{ RAT } & & -0.3553 & & -0.0431 & & -0.1203 & & -0.1940 \\
\hline & & $(-0.67)$ & & $(-0.12)$ & & $(-0.40)$ & & $(-0.73)$ \\
\hline Dummies & YES & YES & YES & YES & YES & YES & YES & YES \\
\hline & & & & & & & & \\
\hline $\mathrm{R}^{2}$ & 0.0308 & 0.0384 & 0.0267 & 0.0349 & 0.0399 & 0.0567 & 0.0229 & 0.0434 \\
\hline & & & & & & & & \\
\hline F-statistic & 3.88 & 1.50 & 3.62 & 1.98 & 3.15 & 6.15 & 3.02 & 2.90 \\
\hline & & & & & & & & \\
\hline Observations & 1112 & 638 & 788 & 465 & 854 & 529 & 1005 & 621 \\
\hline & & & & & & & & \\
\hline Clusters & 84 & 65 & 65 & 48 & 61 & 51 & 63 & 53 \\
\hline
\end{tabular}




\section{Table 5}

\section{Determinants of Hedge Ratio Volatility Conditional on Hedging Activity}

Panel A reports the results of the PROBIT model. The dependent variable is the hedging activity dummy equal to zero if (1) either the firm had zero hedge ratios in both the beginning and the end of quarter $t$; or (2) the firm had zero cash flows from hedging operations in quarter $t-1$. The independent variables are: firm size measured as the logarithm of the market value of assets; market-to-book ratio of assets; ratio of book debt to book equity; quick ratio; dummy variable equal to one if the firm paid quarterly dividend; dummy variable equal to one if a firm reports a credit rating; and Altman's Z-score. Z-statistics are in parentheses and ***, **, and * indicate significance at $1 \%$, $5 \%$, and $10 \%$ level, respectively. Panel B reports the results of the second stage of the two-step Heckman procedure. In the second stage, we estimate the relationship between hedge ratio volatility in quarter $t$ versus cash flows and book profits from derivatives positions in quarter $t-1$, conditional on hedging activity. Hedge ratio volatility is estimated as the absolute value of the difference in the logs of the hedge ratio from the beginning to the end of the quarter. $C F$ is the total derivatives cash flow; $S C F$ is selective hedging cash flow; $B C F$ is the benchmark cash flow; $R B K$ is the change in the book value of derivatives positions. Seasonal dummies are included in each model. The regressions control for the following firm characteristics: firm size measured as the logarithm of the market value of assets; market-to-book ratio of assets; ratio of book debt to book equity; quick ratio; dividend dummy variable equal to one if the firm paid quarterly dividend; credit rating dummy variable equal to one if a firm reports a credit rating; and Altman's Z-score. The regressions include the Inverse Mills ratio estimated on the first stage of the Heckman procedure. $* * * * *, *$ indicate significance at the $1 \%, 5 \%$ and $10 \%$ levels, respectively. Robust $t$-statistics corrected for cluster effects are reported in parentheses.

\section{Panel A. First Stage of the Two-Step Heckman Regression with Selection}

\begin{tabular}{|c|c|c|}
\hline & Probability of Hedgi & sing \\
\hline \multirow{2}{*}{ Intercept } & 0 5400" & \\
\hline & $\begin{array}{r}0.5409 \\
0.10\end{array}$ & 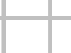 \\
\hline \multirow[t]{2}{*}{ Size } & 0.2403 * & *** \\
\hline & $(4.50)$ & \\
\hline \multirow[t]{2}{*}{ Market-to-book } & $-0.3013^{*}$ & *** \\
\hline & $(-3.91)$ & \\
\hline \multirow[t]{2}{*}{ Debt-to-Equity } & -0.2064 & $n *$ \\
\hline & $(-2.82)$ & \\
\hline \multirow[t]{2}{*}{ Quick ratio } & $-0.0789^{*}$ & *** \\
\hline & $(-4.98)$ & \\
\hline \multirow[t]{2}{*}{ Dividend dummy } & $-0.487^{*}$ & $* *$ \\
\hline & $(-3.25)$ & \\
\hline \multirow[t]{2}{*}{ Credit rating dummy } & 0.0916 & \\
\hline & $(0.61)$ & \\
\hline \multirow[t]{2}{*}{ Altman Z-score } & -0.0193 & \\
\hline & $(-1.25)$ & \\
\hline Pseudo-R $\mathrm{R}^{2}$ & 0.1051 & \\
\hline $\mathrm{Chi}^{2}$ & 86.57 & \\
\hline Observations & 792 & \\
\hline
\end{tabular}


Panel B. Second Stage of the Two-Step Heckman Regression with Selection

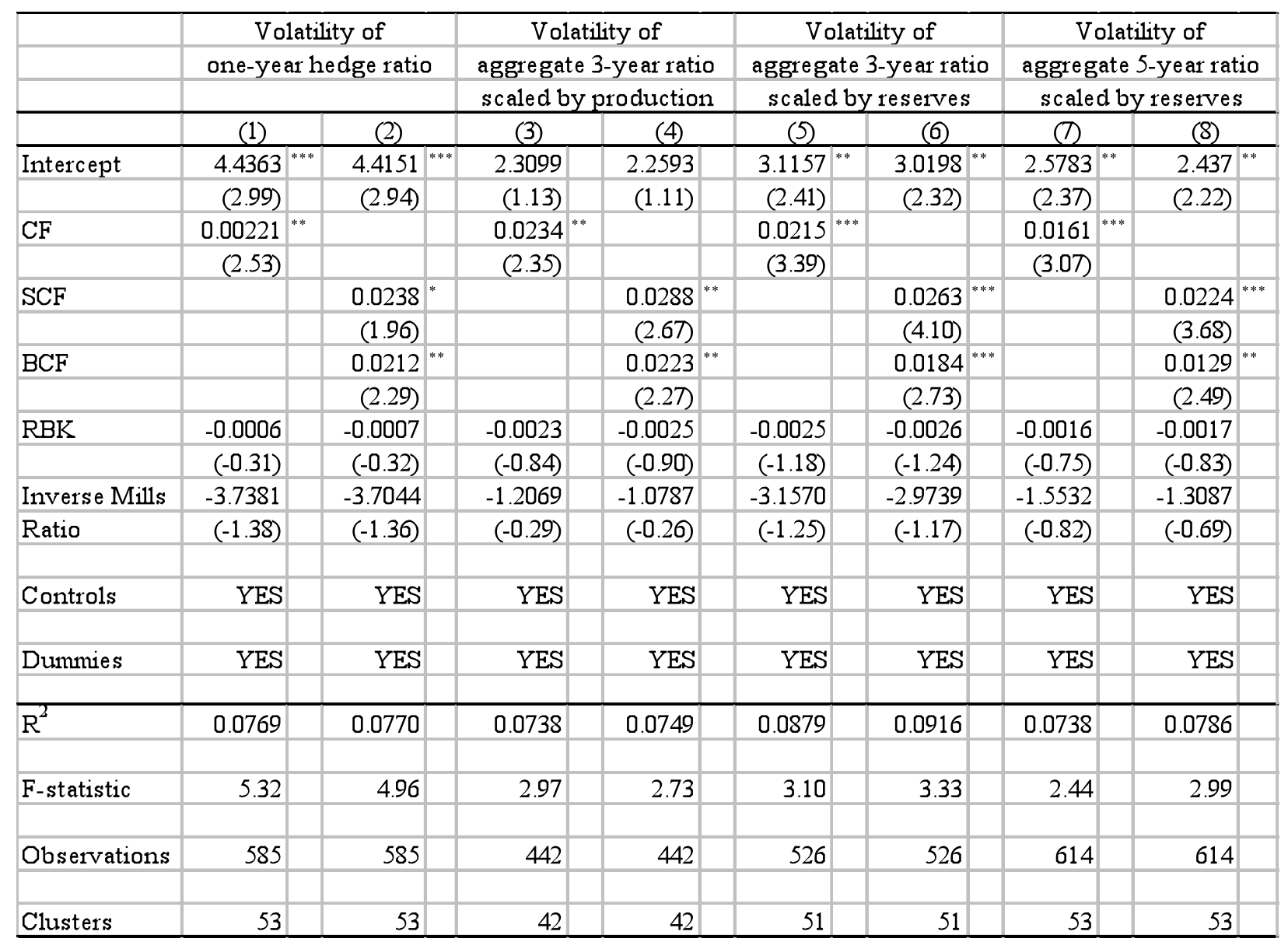


Table 6

\section{Testing for Asymmetric Volatility Response with Selection}

The table reports the results of the second stage of the two-step Heckman procedure. In the first stage, we estimate the likelihood of hedging activity in a given quarter. In the second stage, we estimate the following regression of the three-year aggregate hedge ratio volatility on past selective hedging cash flows from derivatives positions, while allowing for an asymmetric response. The volatility is estimated as the absolute value of the difference in the logs of the hedge ratio in the end and the beginning of the quarter. $S C F$ is the selective hedging cash flow in the previous quarter. $B C F$ is the benchmark cash flow. $I_{1}$ is a dummy variable that equals one if the selective hedging cash flow during the last quarter was positive, and equals zero otherwise; and $I_{2}$ is a dummy variable that equals one if the selective hedging cash flow was negative, and equals zero otherwise. The Inverse Mills ratio is obtained on the first stage of the Heckman procedure. The second-stage regressions includes: firm size measured as the logarithm of the market value of assets; market-to-book ratio of assets; ratio of book debt to book equity; quick ratio; dividend dummy variable equal to one if the firm paid quarterly dividend; credit rating dummy variable equal to one if a firm reports a credit rating; and Altman's Z-score. Seasonal dummies are included in each model and ***, **, * indicate significance at the $1 \%, 5 \%$ and $10 \%$ levels, respectively. Robust t-statistics corrected for cluster effects are reported in parentheses.

\begin{tabular}{|c|c|c|c|c|}
\hline & Volatility of & Volatility of & Volatility of & Volatility of \\
\hline & one-year hedge ratio & aggregate 3-year ratio & aggregate 3-year ratio & aggregate 5-year ratio \\
\hline & & scaled by production & scaled by reserves & scaled by reserves \\
\hline & (1) & (2) & (3) & (4) \\
\hline \multirow[t]{2}{*}{ Intercept } & $4.6787^{* * *}$ & $3.5631^{* *}$ & $3.3262^{* * *}$ & $2.3019^{* *}$ \\
\hline & (3.04) & $(2.07)$ & (2.91) & (2.01) \\
\hline \multirow[t]{2}{*}{$\mathrm{SCF} \times \mathrm{I}$} & $0.0369^{* * *}$ & $0.0280^{*}$ & $0.0292^{* * *}$ & $0.0278^{* * *}$ \\
\hline & (3.85) & (1.84) & $(5.09)$ & $(4.87)$ \\
\hline \multirow[t]{2}{*}{$\mathrm{SCF}^{\times}+\mathrm{I}$} & -0.0207 & 0.0147 & 0.0039 & 0.0025 \\
\hline & $(-1.19)$ & $(1.38)$ & (0.43) & (0.31) \\
\hline \multirow[t]{2}{*}{$\mathrm{BCF}$} & 0.0076 & 0.0097 & 0.0079 & 0.0057 \\
\hline & $(1.00)$ & $(1.57)$ & (1.50) & $(1.82)$ \\
\hline \multirow{2}{*}{$\begin{array}{l}\text { Inverse Mills } \\
\text { Ratio }\end{array}$} & $-4.4532^{* *}$ & -3.57 & $-3.5717^{* *}$ & -1.6059 \\
\hline & $(-2.15)$ & $(-1.45)$ & $(-2.19)$ & $(-1.08)$ \\
\hline \multirow{2}{*}{ Dummies } & YES & YES & YES & YES \\
\hline & & & & \\
\hline \multirow[t]{2}{*}{ Controls } & YES & YES & YES & YES \\
\hline & & & & \\
\hline $\mathrm{R}^{2}$ & 0.077 & 0.0505 & 0.0879 & 0.0781 \\
\hline \multirow[t]{2}{*}{ F-statistic } & 4.6 & 3.43 & 5.48 & 4.24 \\
\hline & & & & \\
\hline \multirow[t]{2}{*}{ Observations } & 588 & 445 & 528 & 610 \\
\hline & & & & \\
\hline Clusters & 53 & 41 & 51 & 53 \\
\hline & & & & \\
\hline
\end{tabular}


Table 7

\section{Testing for Asymmetric Volatility Response without Heckman}

The table reports the results of the regression of the hedge ratio volatility on past selective hedging cash flows from derivatives positions, while allowing for an asymmetric response. The volatility is estimated as the absolute value of the difference in the logs of the hedge ratio in the end and the beginning of the quarter. $S C F$ is the selective hedging cash flow in the previous quarter. $B C F$ is the benchmark cash flow. $I_{1}$ is a dummy variable that equals one if the selective hedging cash flow during the last quarter was positive, and equals zero otherwise; and $I_{2}$ is a dummy variable that equals one if the selective hedging cash flow was negative, and equals zero otherwise. The regressions includes: firm size measured as the logarithm of the market value of assets; market-to-book ratio of assets; ratio of book debt to book equity; quick ratio; dividend dummy variable equal to one if the firm paid quarterly dividend; credit rating dummy variable equal to one if a firm reports a credit rating; and Altman's Z-score. Seasonal dummies are included in each model and $* * *, * * *$ indicate significance at the $1 \%, 5 \%$ and $10 \%$ levels, respectively. Robust t-statistics corrected for cluster effects are reported in parentheses.

\begin{tabular}{|c|c|c|c|c|}
\hline & Volatility of & Volatility of & Volatility of & Volatility of \\
\hline & one-year hedge ratio & aggregate 3-year ratio & aggregate 3-year ratio & aggregate 5 -year ratio \\
\hline & & scaled by production & scaled by reserves & scaled by reserves \\
\hline & (1) & (2) & (3) & $(4)$ \\
\hline \multirow{2}{*}{ Intercept } & 1.7347 & 0.0656 & 0.7499 & 0.9973 \\
\hline & $(0.97)$ & (0.04) & (0.59) & (0.88) \\
\hline \multirow[t]{2}{*}{$\mathrm{SCF} \times I$} & $0.0353^{* *}$ & 0.0133 & $0.0305^{* * *}$ & $0.0268^{* * *}$ \\
\hline & $(2.51)$ & $(1.01)$ & $(3.90)$ & (3.27) \\
\hline \multirow[t]{2}{*}{$\operatorname{SCF} \times 2$} & -0.0156 & 0.0168 & 0.0060 & 0.0055 \\
\hline & $(-0.79)$ & $(1.40)$ & (0.63) & $(0.62)$ \\
\hline \multirow[t]{2}{*}{$\mathrm{BCF}$} & 0.0096 & 0.0073 & 0.0094 & 0.0061 \\
\hline & $(1.60)$ & $(1.48)$ & $(1.84)$ & $(1.59)$ \\
\hline Dummies & YES & YES & YES & YES \\
\hline & & & & \\
\hline Controls & YES & YES & YES & YES \\
\hline \multirow{3}{*}{$\frac{\mathrm{R}^{2}}{}$} & & & & \\
\hline & 0.0189 & 0.0011 & 0.0377 & 0.0322 \\
\hline & & & & \\
\hline \multirow[t]{2}{*}{ F-statistic } & 3.38 & 1.53 & 1.92 & 1.93 \\
\hline & & & & \\
\hline \multirow[t]{2}{*}{ Observations } & 850 & 664 & 724 & 827 \\
\hline & & & & \\
\hline Clusters & 70 & 59 & 59 & 61 \\
\hline & & & & \\
\hline & & & & \\
\hline & & & & \\
\hline & & & & \\
\hline
\end{tabular}




\section{Table 8}

\section{Testing for Asymmetric Volatility Response using Tobit Regression}

The table reports the results of the Tobit regression of the hedge ratio volatility on past selective hedging cash flows from derivatives positions, while allowing for an asymmetric response. The volatility is estimated as the absolute value of the difference in the logs of the hedge ratio in the end and the beginning of the quarter. $S C F$ is the selective hedging cash flow in the previous quarter. $B C F$ is the benchmark cash flow. $I_{1}$ is a dummy variable that equals one if the selective hedging cash flow during the last quarter was positive, and equals zero otherwise; and $I_{2}$ is a dummy variable that equals one if the selective hedging cash flow was negative, and equals zero otherwise. The regressions includes: firm size measured as the logarithm of the market value of assets; market-to-book ratio of assets; ratio of book debt to book equity; quick ratio; dividend dummy variable equal to one if the firm paid quarterly dividend; credit rating dummy variable equal to one if a firm reports a credit rating; and Altman's Z-score. Seasonal dummies are included in each model and $* * *, * * *$ indicate significance at the $1 \%, 5 \%$ and $10 \%$ levels, respectively. The $\mathrm{z}$ statistics are reported in parentheses.

\begin{tabular}{|c|c|c|c|c|}
\hline & Volatility of & Volatility of & Volatility of & Volatility of \\
\hline & one-year hedge ratio & aggregate 3-year ratio & aggregate 3-year ratio & aggregate 5 -year ratio \\
\hline & & scaled by production & scaled by reserves & scaled by reserves \\
\hline & (1) & $(2)$ & (3) & $(4)$ \\
\hline \multirow[t]{2}{*}{ Intercept } & 2.1687 & 0.7770 & $1.1178^{*}$ & $1.5457^{* * *}$ \\
\hline & (0.80) & $(0.89)$ & (1.83) & (2.93) \\
\hline \multirow[t]{2}{*}{$\mathrm{SCF} \times I$} & $0.0461^{* *}$ & $0.0303^{*}$ & $0.0374^{* * *}$ & $0.0316^{* * *}$ \\
\hline & (3.63) & $(1.62)$ & $(4.45)$ & (3.77) \\
\hline \multirow[t]{2}{*}{$\mathrm{SCF} \times 2$} & $-0.0422^{* *}$ & -0.0092 & -0.0069 & -0.0056 \\
\hline & $(-2.20)$ & $(-0.55)$ & $(-0.55)$ & $(-0.40)$ \\
\hline \multirow[t]{2}{*}{$\mathrm{BCF}$} & 0.0085 & 0.0026 & 0.0091 & 0.0047 \\
\hline & $(1.19)$ & $(0.40)$ & (1.70) & $(-0.97)$ \\
\hline Dummies & YES & YES & YES & YES \\
\hline \multirow{2}{*}{ Controls } & & & & \\
\hline & YES & YES & YES & YES \\
\hline & & & & \\
\hline \multirow[t]{2}{*}{ Wald chi2 } & 41.50 & 16.18 & 40.10 & 44.33 \\
\hline & & & & \\
\hline \multirow[t]{2}{*}{ Log Likelihood } & -1809 & -1228 & -1270 & -1524 \\
\hline & & & & \\
\hline Observations & 850 & 664 & 724 & 827 \\
\hline & & & & \\
\hline Groups & 70 & 59 & 59 & 61 \\
\hline & & & & \\
\hline & & & & \\
\hline & & & & \\
\hline & & & & \\
\hline
\end{tabular}




\section{Table 9}

\section{Testing for Asymmetric Response using Cragg Residuals}

The table reports the results of the regression of the average annual Cragg residual (averaged over four quarters) on past annual selective hedging cash flows from derivatives positions, while allowing for an asymmetric response. The Cragg residuals for each quarter are initially estimated as in Adam and Fernando (2006). SCF is the average selective hedging cash flow in the previous year. $B C F$ is the average benchmark cash flow. $I_{1}$ is a dummy variable that equals one if the selective hedging cash flow during the last year was positive, and equals zero otherwise; and $I_{2}$ is a dummy variable that equals one if the selective hedging cash flow was negative, and equals zero otherwise. The regressions includes: firm size measured as the logarithm of the market value of assets; market-to-book ratio of assets; ratio of book debt to book equity; quick ratio; dividend dummy variable equal to one if the firm paid quarterly dividend; credit rating dummy variable equal to one if a firm reports a credit rating; and Altman's Z-score. $* * *, * *, *$ indicate significance at the $1 \%, 5 \%$ and $10 \%$ levels, respectively. The robust $t$-statistics are reported in parentheses.

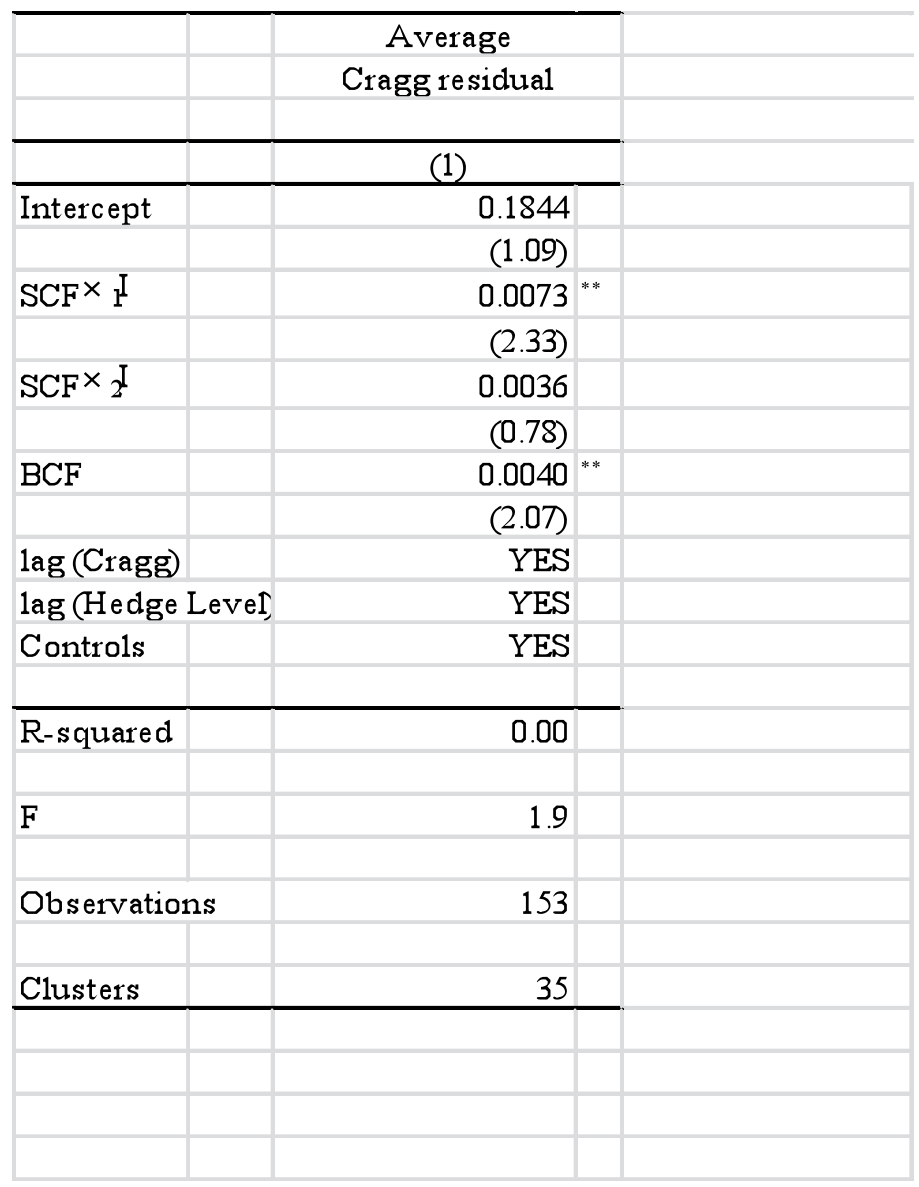




\section{Table 10}

\section{Determinants of Hedge Ratio Volatility Conditional on Hedging Activity Controlling for Managerial Compensation}

The table reports the results of the second stage of the two-step Heckman procedure. In the first stage (see Table 5 Panel A), we estimate the likelihood of hedging activity in a given quarter. In the second stage, we estimate the relationship between hedge ratio volatility in quarter $t$ versus cash flows and book profits from derivatives positions in quarter $t-1$, conditional on hedging activity. Hedge ratio volatility is estimated as the absolute value of the difference in the logs of the hedge ratio from the beginning to the end of the quarter. $C F$ is the total derivatives cash flow; $S C F$ is selective hedging cash flow; $B C F$ is the benchmark cash flow. In Panel A, DELTA_CEO and $V E G A \_C E O$ are the managerial compensation sensitivities for the CEO. In Panel B, DELTA_CFO and $\overline{V E} G A+C F O$ are the managerial compensation sensitivities for the CFO. The regressions include the Inverse Mills ratio estimated on the first stage of the Heckman procedure. ${ }^{* * *}, * *, *$ indicate significance at the $1 \%, 5 \%$ and $10 \%$ levels, respectively. Robust t-statistics corrected for cluster effects are reported in parentheses.

\section{Panel A. CEO}

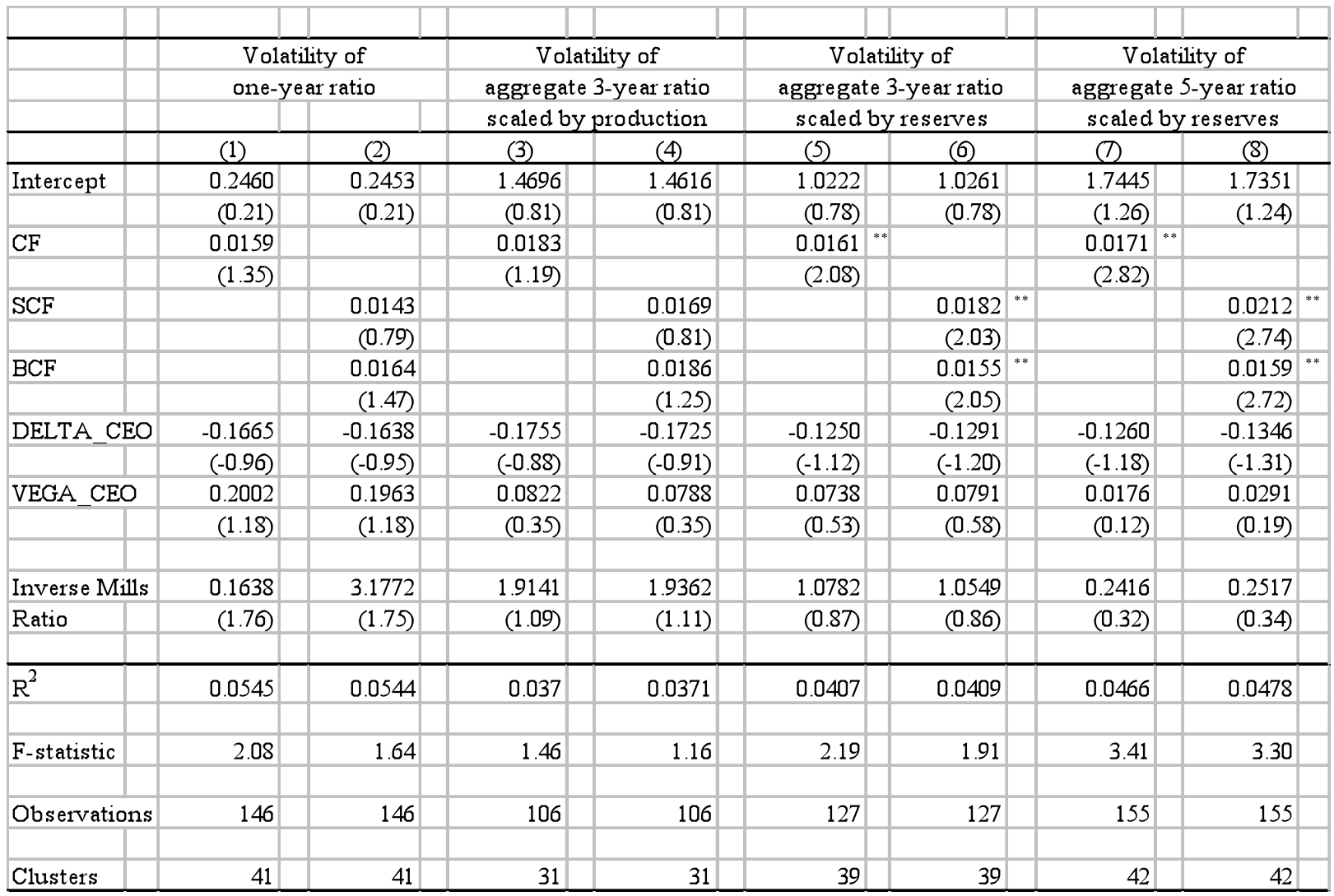




\section{Panel B. CFO}

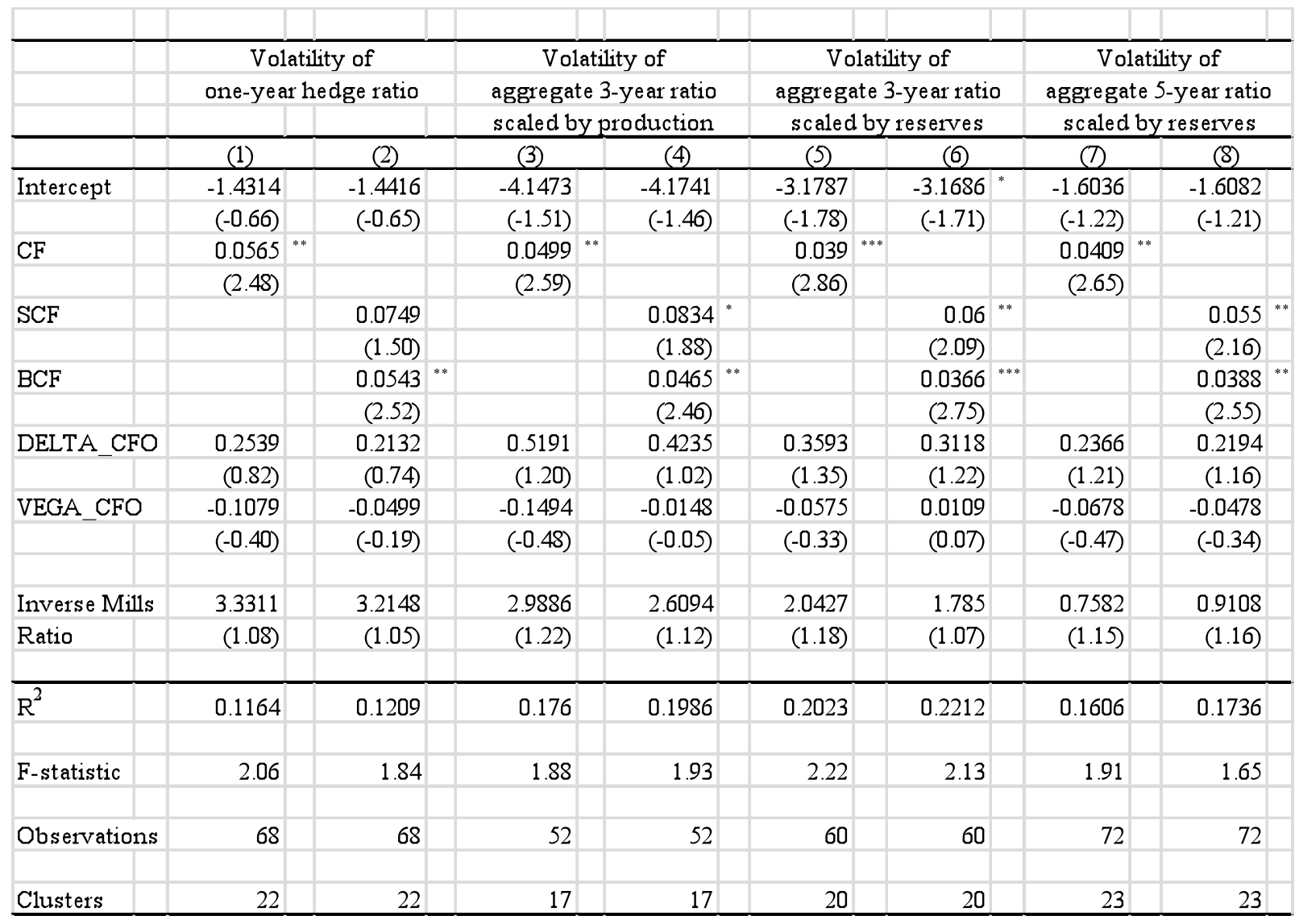




\section{Table 11}

\section{Analysis of Acquisitiveness and Other Corporate Characteristics}

Panel A: cross-sectional descriptive statistics of the sample means of several firm characteristics: $M A$ is the number of attempted merger deals over the sample period; $M A C$ is the number of completed deals; SUCCESS is the percentage of completed deals relative to total attempted; SOUGHT is the fraction of the target firm sought; SUCCESSQ is the fraction bought relative to that sought. Panel B: cross-sectional correlation coefficients between sample means of several firm characteristics. $M A$ is the number of attempted merger deals over the sample period; $V 1$ is the volatility of the one-year hedge ratio; SIZ, firm size measured as the logarithm of the market value of assets; $M B$, market-to-book ratio of assets; $D E$, ratio of book debt to book equity; $Q C K$, quick ratio; $D I V$, dummy variable equal to one if the firm paid quarterly dividend; $R A T$, dummy variable equal to one if a firm reports a credit rating; and Z, Altman's Z-score. ***, **,* indicate significance at the $1 \%, 5 \%$ and $10 \%$ levels, respectively. Panel $\mathrm{C}$ : cross-sectional OLS regression of $M A$ on the other corporate characteristics. ***,**,* indicate significance at the $1 \%, 5 \%$ and $10 \%$ levels, respectively. The t-statistics are reported in parentheses.

\section{Panel A. Descriptive Statistics}

\begin{tabular}{|l|r|r|r|r|r|r|}
\hline Variable & N & Mean & Median & Std Dev & Minimum & Maximum \\
\hline & & & & & & \\
\hline MA & 74 & 7.69 & 4.50 & 7.72 & 1.00 & 39.00 \\
\hline MAC & 74 & 4.26 & 3.00 & 4.24 & 0.00 & 21.00 \\
\hline SUCCESS & 74 & 0.61 & 0.56 & 0.28 & 0.00 & 1.00 \\
\hline SOUGHT & 69 & 68.39 & 66.00 & 26.70 & 1.30 & 100.00 \\
\hline SUCCESSQ & 69 & 0.99 & 1.00 & 0.05 & 0.60 & 1.13 \\
\hline
\end{tabular}

Panel B. Correlations

\begin{tabular}{|c|c|c|c|c|c|c|c|c|c|c|c|c|c|c|c|}
\hline V1 & 1.00 & & & & & & & & & & & & & & \\
\hline & & & & & & & & & & & & & & & \\
\hline MA & $(0.22)$ & * & 1.00 & & & & & & & & & & & & \\
\hline & & & & & & & & & & & & & & & \\
\hline SIZ & $(0.28)$ & *** & 0.49 & *** & 1.00 & & & & & & & & & & \\
\hline & & & & & & & & & & & & & & & \\
\hline DIV & (0.10) & & 0.33 & *** & 0.72 & *** & 1.00 & & & & & & & & \\
\hline & & & & & & & & & & & & & & & \\
\hline RAT & (0.12) & & 0.44 & $* * *$ & 0.53 & $* * *$ & 0.49 & $* * *$ & 1.00 & & & & & & \\
\hline $\mathrm{DE}$ & $(0.07)$ & & $(0,09)$ & & 0.05 & & (口) & & 012 & 100 & & & & & \\
\hline & & & & & & & & & & & & & & & \\
\hline QCK & $(0.07)$ & & 0.10 & & 0.07 & & 0.20 & & (0.00) & $(0.12)$ & 1.00 & & & & \\
\hline $\mathrm{MB}$ & $(0.10)$ & & 0.10 & & 0.34 & *** & 0.36 & *** & 0.08 & 0.01 & 0.45 & *** & 1.00 & & \\
\hline$Z$ & (0.24) & $* *$ & 0.04 & & 0.16 & & 0.24 & ** & $(0.05)$ & $(0.17)$ & 0.80 & $* * *$ & 0.55 & $* * *$ & 1.00 \\
\hline & & & & & & & & & & & & & & & \\
\hline & & & & & & & & & & & & & & & \\
\hline
\end{tabular}

Panel C. Regression Analysis

\begin{tabular}{|c|c|c|c|c|c|c|c|c|c|c|}
\hline Intercept & $\mathrm{SIZ}$ & DIV & RAT & $\mathrm{DE}$ & $\mathrm{QCK}$ & $\mathrm{MB}$ & $Z$ & F-value & Adjusted $\mathrm{R}^{2}$ & Firms \\
\hline-6.31 & 4.12 & -4.93 & $8.96^{* *}$ & $-8.08^{* *}$ & $0.61 *$ & -2.24 & -0.29 & 5.3 & 0.38 & 50 \\
\hline$(-1.39)$ & (3.78) & $(-1.4)$ & $(2.2)$ & $(-2.5)$ & $(1.83)$ & $(-1.08)$ & $(-1.07)$ & & & \\
\hline
\end{tabular}




\section{Table 12}

\section{Correlations between Option Compensation and Selective hedging}

The table presents the descriptive statistics (Panel A) and the cross-sectional correlation coefficients between sample means of several firm characteristics in our sample (Panel B). OCEO is the option compensation of the CEO; OCFO is the option compensation of the CFO; VI is the volatility of the one-year hedge ratio. ${ }^{* * *},{ }^{* *}, *$ indicate significance at the $1 \%, 5 \%$ and $10 \%$ levels, respectively.

\section{Panel A. Descriptive Statistics}

\begin{tabular}{|l|r|r|r|r|r|r|}
\hline & & & & & \\
\hline Variable & $\mathrm{N}$ & Mean & Median & Std Dev & Minimum & Maximum \\
\hline OCEO & 64 & 697,353 & 404,167 & $1,074,571$ & 0.00 & $7,071,429$ \\
\hline OCFO & 60 & 155,277 & 130,500 & 112,981 & 0.00 & 504,375 \\
\hline
\end{tabular}

Panel B. Correlations

\begin{tabular}{llll}
\hline & V1 & OCEO & OCFO \\
\hline V1 & 1.00 & & \\
& & & \\
OCEO & $(0.07)$ & 1.00 & \\
& & & \\
OCFO & $(0.14)$ & $0.66^{* * *}$ & 1.00 \\
\hline
\end{tabular}

